\title{
Diversity, Ecological Role and Biotechnological Potential of Antarctic Marine Fungi
}

\author{
Stefano Varrella ${ }^{1, *(\mathbb{D}}$, Giulio Barone ${ }^{2}$, Michael Tangherlini ${ }^{3}{ }^{\circledR}$, Eugenio Rastelli ${ }^{4}$, Antonio Dell'Anno ${ }^{5}$ and $^{\circ}$ \\ Cinzia Corinaldesi ${ }^{1, *}$
}

1 Department of Materials, Environmental Sciences and Urban Planning, Polytechnic University of Marche, Via Brecce Bianche, 60131 Ancona, Italy

2 Institute for Biological Resources and Marine Biotechnologies, National Research Council (IRBIM-CNR), Largo Fiera della Pesca, 60125 Ancona, Italy; giulio.barone@irbim.cnr.it

3 Department of Research Infrastructures for Marine Biological Resources, Stazione Zoologica "Anton Dohrn", Fano Marine Centre, Viale Adriatico 1-N, 61032 Fano, Italy; michael.tangherlini@szn.it

4 Department of Marine Biotechnology, Stazione Zoologica "Anton Dohrn", Fano Marine Centre, Viale Adriatico 1-N, 61032 Fano, Italy; eugenio.rastelli@szn.it

5 Department of Life and Environmental Sciences, Polytechnic University of Marche, Via Brecce Bianche, 60131 Ancona, Italy; a.dellanno@univpm.it

* Correspondence: s.varrella@univpm.it (S.V.); c.corinaldesi@univpm.it (C.C.)

Citation: Varrella, S.; Barone, G.; Tangherlini, M.; Rastelli, E.; Dell'Anno, A.; Corinaldesi, C. Diversity, Ecological Role and Biotechnological Potential of Antarctic Marine Fungi. J. Fungi 2021,

7, 391. https://doi.org/ 10.3390/jof7050391

Academic Editor: Federico Baltar

Received: 20 April 2021

Accepted: 13 May 2021

Published: 17 May 2021

Publisher's Note: MDPI stays neutral with regard to jurisdictional claims in published maps and institutional affiliations.

Copyright: (c) 2021 by the authors. Licensee MDPI, Basel, Switzerland. This article is an open access article distributed under the terms and conditions of the Creative Commons Attribution (CC BY) license (https:/ / creativecommons.org/licenses/by/ $4.0 /)$.

\begin{abstract}
The Antarctic Ocean is one of the most remote and inaccessible environments on our planet and hosts potentially high biodiversity, being largely unexplored and undescribed. Fungi have key functions and unique physiological and morphological adaptations even in extreme conditions, from shallow habitats to deep-sea sediments. Here, we summarized information on diversity, the ecological role, and biotechnological potential of marine fungi in the coldest biome on Earth. This review also discloses the importance of boosting research on Antarctic fungi as hidden treasures of biodiversity and bioactive molecules to better understand their role in marine ecosystem functioning and their applications in different biotechnological fields.
\end{abstract}

Keywords: marine fungi; mycology; fungal diversity; Antarctica; bioprospecting; psychrophiles; cold-adapted enzymes; industrial applications; blue biotechnologies

\section{Introduction}

The Antarctic ecosystem is one of the most hostile environments on Earth [1]. Despite the harsh environmental conditions (extremely low temperatures, prolonged periods of darkness, and high levels of ultraviolet radiations), Antarctica hosts a variety of unique organisms, from penguins and other endemic birds to whales, seals, fish, and invertebrates inhabiting both the land and the Southern Ocean [2]. Although the number of species inhabiting the Antarctic mainland is low compared to other terrestrial environments [3], the marine ecosystems host an unexpected high biodiversity and an ever-increasing number of species is being reported every year [4-7]. For example, the number of invertebrate marine Antarctic species has been estimated to range from 17,000 to 20,000, only 8000 of which have been described to date $[6,8]$. However, these estimates are likely underrating the overall Antarctic marine diversity due to the low sampling effort and limited spatial coverage of the studies conducted [5,7,9]. Moreover, molecular techniques are now enabling the identification of cryptic and previously unknown species, thus boosting our current ability in assessing Antarctic biodiversity [10].

Many factors can promote the high biodiversity in the Southern Ocean, including high environmental heterogeneity, isolation, and low human impact [4]. Indeed, coastal habitats in Antarctica are characterized by a wide spatial heterogeneity caused by high variability in nutrient dynamics, light availability, and extensive seascape variations due to ice formation and melting which determine major changes in thermohaline conditions, 
biological productivity, and sedimentation processes. Moreover, Antarctica's geographic and oceanographic isolation has allowed many new species to evolve in the absence of competition from lower latitudes' vicariants [4]. Overall, these factors have contributed to shape Antarctic biodiversity in a unique way [11].

The diversity of large organisms inhabiting Antarctic ecosystems has received a larger attention than the diversity of microbial assemblages, although the microbial component represents an important fraction of the whole biomass and plays pivotal roles in biogeochemical cycles and marine food web functioning [12-16]. There is also evidence that microbial diversity represents a major reservoir of novel taxa, biochemical pathways, genes and compounds with biotechnological applications [17-20].

Despite the harsh conditions, fungi are ubiquitously present in Antarctic ecosystems [21]. This success is largely due to the vast array of fungal enzymes, secondary metabolites, and bioactive molecules, which allowed fungal colonization and diversification in almost every habitat on Earth [22]. Their peculiar biological adaptions to low temperatures lead to the production of structurally novel enzymes and bioactive metabolites, which provide fungi competitive advantages over other microorganisms through chemicallymediated interactions, defense, and virulence factors for plants and animals [23-26]. In the last decade, several studies, exploring the fungal diversity in Antarctic marine environments, have revealed promising properties of fungi relevant for biotechnological applications (e.g., pharmaceutical, food, and cosmeceutical industries [27-29]). Indeed, increasing evidence indicates that cold-adapted fungi are a relevant target to the present and future scientific research for their possible biotechnological applications, including the development of new drugs and exploitation in several industrial processes [30,31].

In this review we collected the current literature about fungi in Antarctic marine ecosystems, focusing on their taxonomic diversity and ecological functions, as well as their potential for developing new blue biotechnologies.

\section{Fungal Diversity and Ecology in Antarctic Marine Environments}

Fungi are widely distributed in marine Antarctic ecosystem, and their occurrence has been recorded in seawater and sediments as well as associated with macroalgae and invertebrates [27]. Marine fungi are supposed to contribute to population dynamics, C and nutrient cycles in the oceans [32], and yet only a limited number of studies have investigated fungal diversity and ecology of Antarctic marine fungi. These studies mainly focused on the identification of fungi and yeasts isolated from waters, sediments, animals, and/or macroalgae (Figure 1). So far, most of the information has been acquired through culture-dependent approaches on samples collected from the Shetland Islands, leaving most coastal and offshore habitats unexplored.

\subsection{Fungal Diversity}

\subsubsection{Fungi in Antarctic Marine Environment}

In the last years, culture-dependent and molecular techniques have allowed us to describe a large number of fungal taxa in seawater $[33,34]$. Likewise, fungi have been identified in several polar environments [35-37]. To date, only a few studies have successfully identified filamentous fungi and yeasts in both coastal and offshore Antarctic waters [38,39]. These studies, employing culture-dependent methods, have been able to isolate a number of fungal genera belonging to the orders Eurotiales, Hypocreales, Chaetothyriales, and Kriegeriales. In particular, Antarctic waters seem to exclusively host the genera Exophiala, Graphium, Simplicillium, Purpureocillium, and Akanthomyces. These genera are known to include parasites, pathogens, and likely saprotrophs, which may be involved in complex interactions within the water column [40-42]. However, other genera found in Antarctic waters such as Penicillium, Metschnikowia, Rhodotorula, and Glaciozyma have also been found elsewhere in Antarctica (Figure 2; Table S2). Within the water column, fungi can have significant effects on primary production dynamics and carbon fluxes within the marine food webs, by acting as saprotrophs and interacting with marine phytoplankton [37,43,44]. 


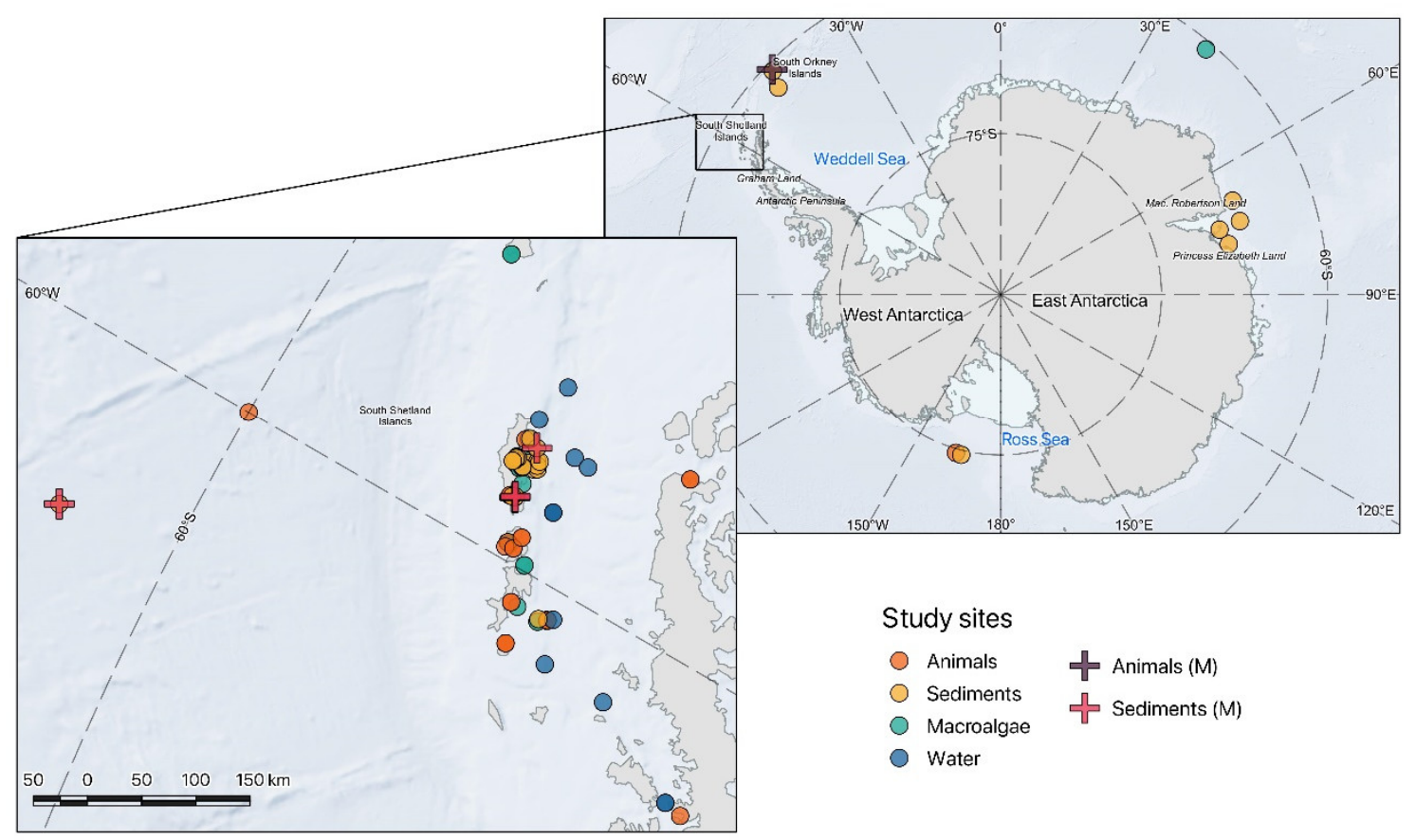

Figure 1. Locations of the fungi identified from different Antarctic marine substrates: animals (orange circle), sediments (yellow circle), macroalgae (green circle), and water (blue circle) based on culture dependent approaches or identified through metagenomic analysis: animals (purple cross) and sediments (pink cross) (for detailed elucidation on the samples where fungal taxa were isolated, and coordinates see Table S1).

Despite the increasing number of investigations carried out worldwide, to date, fungal diversity in Antarctic sediments has been explored in a relatively limited number of studies, which mainly focused on the diversity of culturable fungal species [45-61]. Recently, for the first time, molecular tools have been employed to investigate the fungal diversity in Antarctic marine sediments and allowed the identification of a large number of fungal taxa although much of the fungal diversity in Antarctic marine sediments still remains unknown [49].

Antarctic marine sediments have been shown to host a plethora of fungal taxa. For example, the genera Pseudocercosporella, Toxicocladosporium, Trichoderma, Humicola, Paraconiothyrium, Phaeoacremonium, and Phenoliferia have been documented exclusively in marine sediments and to be potentially involved in the degradation of organic matter. Nonetheless, fungal diversity in marine sediments also include many other genera found in other Antarctic habitats, such as Penicillium, Metschnikowia, Rhodotorula, Cladosporium and Glaciozyma (Figure 2). The genus Pseudogymnoascus genus found in Antarctic sediments has been also recorded in other cold environments including polar regions and glaciers $[27,49,62,63]$, and the genus Phaeosphaeria, whose members include plant pathogens, has been also found in association with the Antarctic macroalgae Adenocystis utricularis [64,65]. 


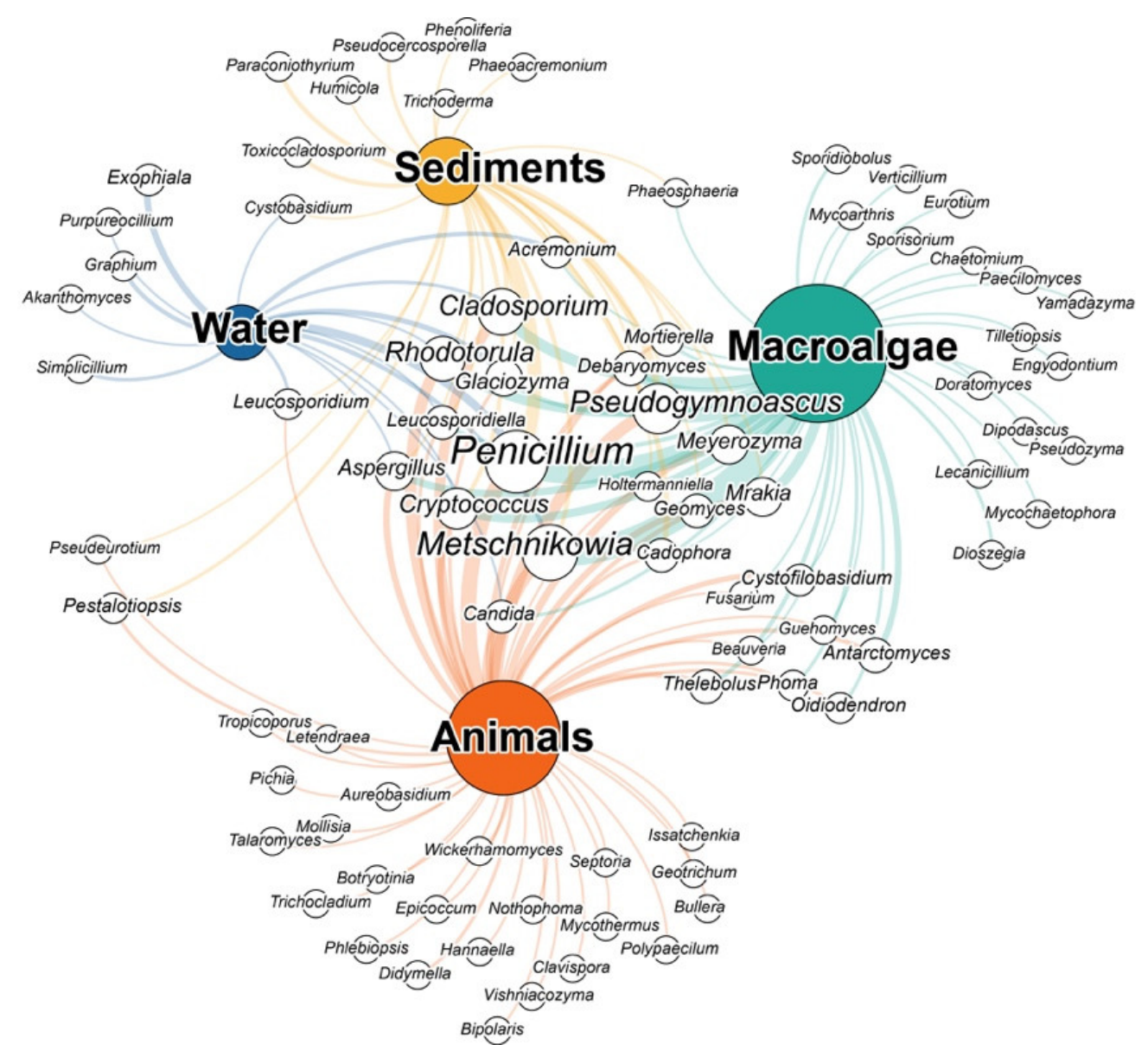

Figure 2. Network diagram displaying the records of Antarctic fungal taxa belonging to different genera identified through culture dependent approaches or metagenomic analyses in the four most commonly marine matrices (water, sediments, animals, macroalgae). The size of the white nodes is proportional to the number of records in the studies in which the genus has been found, while the size of coloured nodes is proportional to the overall number of genera retrieved.

\subsubsection{Fungi Associated with Antarctic Macroalgae and Animals}

Most of the research on Antarctic fungi focused on the assemblages associated with benthic macroalgae of the South Shetland Islands (Antarctic Peninsula) $[54,64,66-70]$. In particular, the macroalgae Adenocystis utricularis, Desmarestia anceps and Palmaria decipiens host a rich fungal diversity, including genera like Pseudogymnoascus, Antarctomyces, Oidiodendron, Penicillium, Phaeosphaeria, Cryptococcus, Leucosporidium, Metschnikowia, and Rhodotorula. Some of the species belonging to these genera appear to be endemic of Antarctica (i.e., Antarctomyces pellizariae, Antarctomyces psychrotrophicus, Cryptococcus victoriae, Cryptococcus adeliensis, Metschnikowia australis, Pseudogymnoascus pannorum, Mortierella antarctica), while others appear rather ubiquitously distributed (i.e., Penicillium sp., Aureobasidium sp. and Rhodotorula sp.) $[64,66,68,69]$. Despite this, fungi associated with macroalgae are apparently unique since several genera have never been found in any other marine sample (Figure 2). This rich and diverse fungal assemblages can have an important ecological role since they may produce enzymes with the potential to degrade algal detritus and may be involved in organic matter cycling and energy transfer within the marine food web [69].

Analogously to what has been reported for macroalgae, fungi have been isolated also from marine animals, with which they can interact as pathogens, parasites, or symbionts [71-78]. Nevertheless, the nature and the strength of the relationships between the host and the associated fungi have yet to be fully understood [78]. Fungal diversity has been investigated in a variety of Antarctic organisms such as sponges, annelids, crus- 
taceans, molluscs, and echinoderms collected in the South Shetland Islands (Figure 1), mainly through culture-dependent approaches [54,79-83]. Although culture-based studies allowed isolating and investigating a variety of fungal taxa, molecular tools have allowed the identification of a larger fraction of the fungal diversity provided. In particular, such molecular methods provided new information about the fungal diversity associated with the Antarctic Krill, Euphausia superba [84], and the marine sponges Leucetta antarctica and Myxilla sp. [85]. Several other fungal taxa, including members of the orders Saccharomycetales and Eurotiales, and of the families Saccharomycetaceae and Aspergillaceae, have been identified. In particular, the most represented taxa included ubiquitous genera such as Rhodotorula, Penicillium, Metschnikowia, Aspergillus, as well as 23 different exclusive genera such as Wickerhamomyces, Geotrichum, Letendraea, and Bullera (Figure 2). Among them, Wickerhamomyces spp. has particular characteristics: It can in fact grow under extreme environmental stressful conditions, such as low and high $\mathrm{pH}$, high osmotic pressure, absence of oxygen, and also shows antimycotic activity [86]. Despite further studies being needed to better understand the ecological significance of fungal-host interactions, there is evidence that these fungi can be involved in defensive mechanisms by producing cytotoxic, antimycotic, and antibiotic molecules, which could increase the animal's wellbeing [83]. For instance, fungi associated with the Antarctic krill can be involved in the defense mechanisms of the host against pathogenic bacteria [83]. Nevertheless, a number of fungal pathogens (i.e., Rhodotorula, Debaryomyces) have been isolated from marine organisms which have the ability to compromise host health and fitness, but their possible detrimental effects on marine fauna have not yet been estimated.

\subsection{Contribution of Fungi to Ecological Processes in Antarctic Marine Ecosystems}

While on terrestrial ecosystems the role of fungi is largely recognized, their ecological role in Antarctic marine ecosystems has yet to be understood. In the last decade, several studies highlighted that fungi are widely distributed in marine environments, from coastal waters [87] to the deep-sea surface and subsurface sediments [88-94], extreme habitats such as hypersaline anoxic basins [95-97], cold seeps [98-100], hydrothermal vents [101,102], and oil reservoirs [103]. Polar environments are also characterized by a considerably high number of fungal taxa $[36,55,104-106]$, which can be involved in organic matter degradation and nutrient cycling, as well as in intimate relationships with a variety of organisms $[27,32,49,107]$.

In Antarctic marine waters, owing to their unique enzymatic capabilities and metabolic versatility $[29,108,109]$, fungi can be important components for the biogeochemical processes and the functioning of the food webs [110]. As saprotrophs, some fungi may utilize phytoplankton-derived detritus contributing to organic matter fluxes [111], while others can interact with planktonic microorganisms influencing ecological dynamics and food webs [112]. The same Authors have provided a theoretical framework to describe how aquatic fungi interact with their environment, introducing the concept "mycoflux" to refer to the interactions between pelagic fungi and other microbes and their effects on the carbon pump [112]. Previously, Kagami et al. (2014) introduced the concept "mycoloop" to indicate the parasitic interaction between fungi and other planktonic components, suggesting that parasitic fungi can facilitate energy transfer from phytoplankton to zooplankton [113]. This concept is also supported by recent metabarcoding and metagenomic studies carried out in different aquatic environments $[37,114,115]$, which revealed a high diversity of parasitic (or facultative parasitic) zoosporic fungi associated with phytoplankton and zooplankton $[43,113,116-120]$. Overall, these findings suggest that fungal parasites can be important in influencing the aquatic food webs as other planktonic parasites [121].

Even in Antarctic benthic ecosystems, fungi can have an important role in $\mathrm{C}$ cycling and nutrient regeneration processes. Benthic fungi, acting as decomposers of organic matter can be involved in the degradation of recalcitrant organic compounds, which otherwise accumulate in marine sediments $[93,122,123]$, and may mediate $C$ and energy transfer to higher trophic levels [112,124-126]. The association of fungi with microalgal [43] and 
macroalgal detritus can improve the nutritional value of organic matter by lowering the carbon:nitrogen:phosphorus ratio [127,128]. Moreover, fungi in Antarctic benthic ecosystems are likely involved in ecological interactions with other eukaryotes, similarly to what observed in other extreme marine environments acting as pathogens and parasites $[129,130]$.

In Antarctic benthic coastal ecosystems, an important relationship between fungi and macroalgae has been reported [64]. Macroalgae are ecosystem engineers that contribute to primary production in cold and temperate coastal marine environments [131]. Macroalgae represent the second biggest reservoir of fungal diversity after sponges [132], and the relationship between the host and its fungal assemblage encompasses mutualism, parasitism, and saprophytism [133-135]. In this relationship, fungi can provide important advantages for the growth, defence, development, and nutrition of the algal host [136-138]. However, several fungi can also act as pathogens, compromising the host's health and its ecological functions [139].

Fungi have also been documented in association with Antarctic benthic marine animals [27,54], but so far, the nature and the mechanisms of these relationships remain mostly unknown. To date, only one study based on a functional analysis of fungi associated with sponges highlighted that fungi can have an important role in the degradation of the organic matter, contributing to nutrient cycling and in turn influencing the carbon fixation pathways of prokaryotes and other micro-eukaryotes within the microbial assemblages [85].

Paradoxically, the biotechnological focus of the Antarctic marine fungi has contributed to accumulate more information on their potential industrial applications than on their quantitative relevance and role in biodiversity and functioning of Antarctic marine ecosystems. Only one study, indeed, has so far addressed the ecological role of fungi in Antarctic marine habitats [85]. This knowledge gap highlights the importance to increase studies based on molecular and biochemical tools to better comprehend fungal diversity and ecology and to elucidate the nature and strength of the relationships between fungi and their hosts especially in extreme environments of the Earth, such as the Antarctic ecosystems.

\section{Biotechnological Potential of Fungi Inhabiting Marine Antarctic Environments}

The extreme conditions of Antarctic marine environments have forced microorganisms to evolve peculiar metabolic pathways as well as adaptive mechanisms, which allow them to thrive in cold ecosystems [140]. Psychrophilic and psychrotrophic fungi hold outstanding biological features arising from the harsh environmental conditions with which they must cope [141,142]. For these reasons, they are considered treasure of unique enzymes and bioactive molecules with an exceptional application potential $[29,109,143-146]$. Therefore, Antarctic fungi can greatly contribute to the discovery of new compounds of marine origin to be exploited in the industrial "white" and bio-pharmaceutical "red" biotechnology $[28,147]$.

\subsection{Antarctic Marine Fungi: Promising Candidates for Bioprospecting}

With the increasing demand for novel antimicrobial and chemotherapeutic drugs, the discovery of biologically active molecules to improve human health is one of the most important challenges for mankind [148,149]. There is a general consensus that natural products offer extraordinary advantages over chemical molecules, and this makes marine microorganisms an astonishing potential source of new drugs [150-154]. Marine extremophilic microorganisms, including fungi, can also represent a huge reservoir of bioactive molecules that have recently triggered interest in bioprospecting research because of their promising therapeutical properties [21,22,29,109,152,155-159]. In this regard, marine fungi isolated from polar environments reported their ability to synthesize metabolites with unique structures and a wide range of biological activities, compared to mesophilic fungi, highlighting that psychrophilic fungi can be a new resource for several applications in biotechnology $[28,30,160-162]$. However, the search for natural bioactive products 
has been focused so far on a very small number of fungi isolated from Antarctic marine sediments, seawater and few organisms such as sponges and macroalgae [27].

Crude extracts of fungal strains have been isolated from fresh thalli of Antarctic macroalgal species and tested for their antibiotic, antifungal, antiviral, and antiparasitic activity [66]. Among these, extracts of two Penicillium species associated to the endemic macroalgae Palmaria decipiens and Monostroma hariotii contained compounds with high and selective antifungal and trypanocidal activities [68]. In addition, extracts of Pseudogymnoascus species, Guehomyces pullulans, and Metschnikowia australis showed high antifungal activity against Candida albicans, Candida krusei, and Cladosporium sphaerospermum, whereas the extract of Penicillium steckii greatly inhibited BHK-21 cell line expressing the yellow fever virus [68]. Moreover, Geomyces species associated with Antarctic marine sponges, have been suggested as a source of several promising antimicrobial and antitumoral compounds [82].

Interestingly, extracts of Pseudogymnoascus 5A-1C315IIII, isolated from marine sediments of Admiralty Bay (South Shetland Islands, Antarctica), can inhibit different phytopathogenic Xanthomonas species [57,58]. Another survey conducted on marine sediments collected at Deception Island (South Shetland Islands, Antarctica) led to the isolation of Pseudogymnoascus specie and Simplicillium lamellicola, which showed high and selective antifungal activity against Paracoccidioides brasiliensis [104].

Despite the considerable number of crude fungal extracts, only a few bioactive compounds have been actually tested so far (Table 1). Most of the research on the bioactive compounds carried out in Antarctic environments mainly focus on a few Penicillium strains, leaving most of the actual fungal biodiversity largely unexplored. The bioprospection of psychrophilic and psychrotolerant polar Penicillium strains have resulted in the collection of many promising bioactive molecules with a complex and peculiar structure and a broad range of biological activities, highlighting their outstanding potential [162]. For instance, eremophilane-type sesquiterpene isolated from Penicillium sp. PR19N-1, showed potent inhibitory activity against A549 tumor cells with IC50 value of $5.2 \mu \mathrm{M}[51,163]$. In a recent study, neuchromenin, extracted from Penicillium glabrum SF-7123, has shown great anti-inflammatory effects inactivating the NF- $\mathrm{kB}$ and p38 MAPK pathways in BV2 and RAW264.7 cells [50]. 


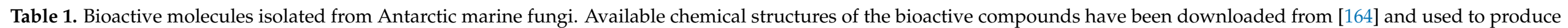
Figures S1-S3 for ease of visualization.

\begin{tabular}{|c|c|c|c|c|}
\hline Fungal Taxa & Product & Bioactivity & Source & Ref. \\
\hline $\begin{array}{l}\text { Penicillium citrinum } \\
\text { OUCMDZ4136 }\end{array}$ & $\begin{array}{l}\text { 2,4-Dihydroxy-3,5,6-trimethylbenzoic acid; } \\
\text { Citreorosein; Pinselin; Citrinin; } \\
\text { Dihydrocitrinone; Pennicitrinone A; } \\
\text { Quinolactacin A1 }\end{array}$ & $\begin{array}{c}\text { Cytotoxic activities against MCF-7, A549, K562 } \\
\text { cell lines }\end{array}$ & Antarctic krill Euphasia superba & [83] \\
\hline Penicillium citreonigrum SP-6 & Diketopiperazine, phenols & Inhibitory activity against HCT116 cancer cell line & $\begin{array}{l}\text { Marine sediment, Great Wall } \\
\text { Station }\end{array}$ & [165] \\
\hline Penicillium crustosum HDN153086 & Diketopiperazine & Cytotoxic activities against K562 cell line & Marine sediment, Pridz Bay & {$[61]$} \\
\hline Penicillium crustosum PRB-2 & Penilactone A & $\begin{array}{l}\text { NF-KB inhibitory activities of HCT-8, Bel-7402, } \\
\text { BGC-823, A549 and A2780 tumor cell lines }\end{array}$ & Deep-sea sediment, Prydz Bay & [46] \\
\hline Penicillium glabrum SF-7123 & $\begin{array}{l}\text { Citromycetin derivative, neuchromenin; } \\
\text { myxotrichin } C \text {, deoxyfunicone; }\end{array}$ & Anti-inflammatory; tyrosine phosphatase 1B inhibition & Marine sediment, Ross Sea & {$[50]$} \\
\hline $\begin{array}{l}\text { Penicillium granulatum } \\
\text { MCCC 3A00475 }\end{array}$ & Spirograterpene A & $\begin{array}{l}\text { Antiallergic effect on immunoglobulin E } \\
\text { (IgE)-mediated rat mast RBL-2H3 cells }\end{array}$ & Deep-sea sediment, Prydz Bay & {$[52]$} \\
\hline Penicillium sp. PR19N-1 & $\begin{array}{l}\text { Chlorinated eremophilane sesquiterpenes, } \\
\text { eremofortine C, eremophilane-type } \\
\text { sesquiterpenes, eremophilane-type lactam }\end{array}$ & $\begin{array}{l}\text { Cytotoxic activity against HL-60 and A549 cancer } \\
\text { cell lines }\end{array}$ & Deep-sea sediment, Prydz Bay & {$[51,163]$} \\
\hline Penicillium sp. S-1-18 & $\begin{array}{c}\text { Butanolide A, guignarderemophilane } \mathrm{F}, \\
\text { xylarenone A }\end{array}$ & $\begin{array}{c}\text { Butanolide: inhibitory activity against tyrosine } \\
\text { phosphatase 1B; xylarenone A: antitumor activity } \\
\text { against HeLa and HepG2 cells and growth-inhibitory } \\
\text { effects against pathogenic microbes }\end{array}$ & Sea-bed sediment & {$[60,166]$} \\
\hline $\begin{array}{l}\text { Penicillium sp. UFMGCB } 6034 \text { and } \\
\text { UFMGCB } 6120\end{array}$ & Aromatic compounds & Antifungal and trypanocidal activities & $\begin{array}{l}\text { Macroalgae: Palmaria decipiens and } \\
\text { Monostroma hariotii }\end{array}$ & {$[66]$} \\
\hline Pseudogymnoascus sp. & $\begin{array}{c}\text { Pseudogymnoascin A, B, C, 3-nitroasterric acid; } \\
\text { Geomycins B, C }\end{array}$ & Antibacterial and antifungal activities & Sponge genus Hymeniacidon & {$[167,168]$} \\
\hline Trichoderma asperellum & Asperelines A-F, peptaibols & Not assayed & Marine sediment, Penguin Island & {$[56,169]$} \\
\hline
\end{tabular}


The fungus Penicillium crustosum HDN153086, isolated from Antarctic sediment from Prydz Bay, can synthesize a new diketopiperazine with moderate cytotoxic activity against K652 cell lines [61]. Interestingly, seven bioactive compounds extracted from Penicillium citrinum OUCMDZ4136, associated with the Antarctic krill Euphausia superba, showed moderate to strong cytotoxicity against A549, K562, and MCF-7 cell lines [83]. Conversely, Pseudogymnoascus, Trichoderma, Aspergillus, and other fungal genera isolated from macroorganisms living in Antarctic environments, have not received as much attention as the Penicillium genus. In fact, to date, only a few studies investigated the properties of bioactive molecules extracted from these isolated genera and tested their bioactivity [56,167-169]. For instance, different compounds have been extracted from Pseudogymnoascus; however, only two bioactive molecules (Geomycins B, C) from a sediment sample showed antifungal and antimicrobial activities [168].

\subsection{Antarctic Fungi as Novel Source of Cold-Active Enzymes}

Over the last 20 years, the interest in cold-adapted microorganisms as a source of new enzymes for industrial processes has intensely grown [170-172]. Nowadays, a considerable number of industrial processes and products take advantage of microbial enzymes [173,174]. Nevertheless, studies prospecting and characterizing enzymes have mainly focused on prokaryotes $[175,176]$, while there is little information on enzymes from psychrophilic or psychrotolerant eukaryotes inhabiting Antarctic systems [162,177,178].

Despite the increasing demand for new biocatalysts, very few enzymes are currently isolated from extreme environments, the so-called "extremozymes" [179]. Cold extremozymes display a greater versatility and adaptability with respect to their nonextreme counterparts that can be advantageous for modern industries [180]. These enzymes are an optimal alternative to their mesophilic equivalents thanks to their higher stability under various physicochemical conditions (i.e., $\mathrm{pH}$, temperature, salinity) and their advantage to reduce costs and energy consumption [181-185]. Indeed, the use of these enzymes represents an eco-friendly method compared to the chemical procedures employed in many industrial processes, allowing to avoid the use of organic solvents and other hazardous compounds that can be seriously harmful to the environment [186]. Nevertheless, only some of these potentially useful enzymes have been successfully introduced in the market so far, and their use is spreading rather slowly [187]. This is mainly due to several steps including chemical characterization, condition optimization, and process validation that need to be passed for commercializing novel biocatalysts [188]

Antarctic environments are a relatively new frontier for the isolation of cold-active enzymes. These molecules have distinct features that meet the need of green industry applications $[162,177,189,190]$. In this view, psychrophilic and psychrotolerant fungi are specialized in producing extracellular and intracellular cold active-enzymes $[20,189,191]$, which they use to live in harsh conditions to degrade molecules and for the uptake of nutrients [141,170,192-194]. Recently, these cold-adapted enzymes have attracted growing interest because of their potential benefits in several industrial fields [175,185,195]. The main characteristics of fungal extremozymes are the high activity at low temperatures and thermolability, which have been manly gained the attention for being applied as detergent additives (e.g., lipases) for eco-friendly cold-water washing and for food, biofuel, and textile processing $[184,185]$. Among them, cold-adapted hydrolases (EC 3.x, proteases, lipases, cellulases, glycosidases) can be employed and useful in a variety of biotechnological processes (i.e., food, beverage, cleaning agents, textiles, biofuels, and pulp and paper; see Table 2). This class of enzymes is extremely important since it covers over $90 \%$ of the total industrial enzymes market [196,197]. 


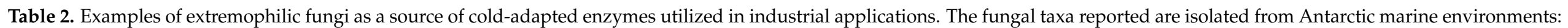
seawater, marine sediments, and organisms.

\begin{tabular}{|c|c|c|c|c|c|}
\hline Enzyme & Reaction & Fungi & $\begin{array}{c}\text { Source of } \\
\text { (Isolate) Sample }\end{array}$ & Applications/Potential Uses & Ref. \\
\hline $\begin{array}{l}\text { Carragenase } \\
\text { (EC 3.2.1.83) }\end{array}$ & $\begin{array}{l}\text { Hydrolysis of } 1,4-\beta \text {-linkages } \\
\text { between galactose } 4 \text {-sulfate } \\
\text { and 3,6-anhydro-galactose to } \\
\text { produce kappa-carrageenans }\end{array}$ & $\begin{array}{l}\text { Pseudogymnoascus sp. } \\
\text { UFMGCB } 10054\end{array}$ & Macroalga: Iridaea cordata, & $\begin{array}{l}\text { Biomedical field, textile industry, bioethanol } \\
\text { production, and detergent additive }\end{array}$ & [69] \\
\hline $\begin{array}{l}\text { Cellulase } \\
\text { (EC 3.2.1.4) }\end{array}$ & $\begin{array}{l}\text { Cellulose hydrolysis } \\
\text { into glucose }\end{array}$ & $\begin{array}{l}\text { Cystofilobasidium infirmominiatum } \\
\text { 071209-E8-C1-liblev; Metschnikowia } \\
\text { australis, Rhodotorula glacialis; Candida } \\
\text { spencermartinsiae, Leucosporidiella } \\
\text { creatinivora, Leucosporidium scottii }\end{array}$ & $\begin{array}{l}\text { Marine sponge: Tedania; } \\
\text { marine } \\
\text { sediments; seawater }\end{array}$ & $\begin{array}{c}\text { Food industry, animal feed, beer and wine, textile } \\
\text { and laundry, pulp and paper industry, agriculture, } \\
\text { biofuel, pharmaceutical industries, and } \\
\text { waste management }\end{array}$ & {$[45,80]$} \\
\hline $\begin{array}{l}\text { Chitinase } \\
\text { (EC 3.2.1.14) }\end{array}$ & $\begin{array}{l}\text { Cleavage of glycosidic } \\
\text { linkages in chitin and } \\
\text { chitodextrins generating } \\
\text { chitooligosaccharides }\end{array}$ & $\begin{array}{l}\text { Lecanicillium muscarium CCFEE-5003; } \\
\text { Glaciozyma antarctica PI12 }\end{array}$ & Shrimp wastes; seawater & $\begin{array}{l}\text { Cosmetic, pharmaceutic fields, fermentation } \\
\text { research, and biomedicine }\end{array}$ & {$[45,198-202]$} \\
\hline $\begin{array}{l}\text { Endo- } \beta-1,3(4)- \\
\text { glucanase } \\
\text { (EC 3.2.1.6) }\end{array}$ & $\begin{array}{l}\text { Endohydrolysis of }(1 \rightarrow 3) \text { - or } \\
\quad(1 \rightarrow 4) \text {-linkages in } \\
\beta \text {-D-glucans }\end{array}$ & Glaciozyma antarctica PI12 & Seawater & $\begin{array}{l}\text { Brewing and animal, feed-stuff industry, biofuel } \\
\text { production, and pharmaceuticals }\end{array}$ & [202-204] \\
\hline $\begin{array}{c}\text { Esterase } \\
(\text { EC 3.1.1.1) }\end{array}$ & $\begin{array}{l}\text { Hydrolyis of short acyl-chain } \\
\text { soluble esters }\end{array}$ & $\begin{array}{l}\text { Cryptococcus victoriae, Metschnikowia } \\
\text { australis, Rhodotorula glacialis, } \\
\text { Leucosporidium scottii, Leucosporidiella } \\
\text { creatinivora; Glaciozyma antarctica }\end{array}$ & $\begin{array}{l}\text { Marine sediments; } \\
\text { seawater, sea ice }\end{array}$ & $\begin{array}{l}\text { Paper bleaching, bioremediation, degradation, and } \\
\text { removal of xenobiotics and toxic compounds }\end{array}$ & {$[45,205]$} \\
\hline $\begin{array}{l}\text { Invertase } \\
(\mathrm{EC} 3.2 .1 .26)\end{array}$ & $\begin{array}{l}\text { Hydrolysis of the terminal } \\
\quad \text { non-reducing } \\
\beta \text {-fructofuranoside residue in } \\
\text { sucrose, raffinose and related } \\
\quad \beta \text {-D-fructofuranosides }\end{array}$ & $\begin{array}{l}\text { Glaciozyma antarctica } 17 \text { (formerly } \\
\text { Leucosporidium antarcticum) }\end{array}$ & Seawater & $\begin{array}{l}\text { Beverage, confectionary, bakery, invert sugar, high } \\
\text { fructose syrup, artificial honey, calf feed, food } \\
\text { for honeybees }\end{array}$ & {$[38]$} \\
\hline $\begin{array}{c}\text { Laccase } \\
(\text { EC 1.10.3.2) }\end{array}$ & $\begin{array}{l}\text { Oxidation of phenolic } \\
\text { compound like lignin }\end{array}$ & $\begin{array}{c}\text { Cadophora malorum A2B, Cadophora } \\
\text { malorum AS2A, Cadophora } \\
\text { luteo-olivacea P1 }\end{array}$ & Marine sediments & $\begin{array}{l}\text { Biosensors, microfuel and bioelectrocatalysis, food, } \\
\text { pharmaceutic, cosmetic, pulp and paper, textile } \\
\text { industries, and bioremediation }\end{array}$ & [206] \\
\hline $\begin{array}{l}\text { Lignin peroxidase } \\
\quad(\mathrm{EC} \text { 1.11.1.14) }\end{array}$ & $\begin{array}{l}\text { Oxidative breakdown } \\
\text { of lignin }\end{array}$ & $\begin{array}{l}\text { Cadophora malorum M7, } \\
\text { Cadophora sp. OB-4B }\end{array}$ & Marine sediments & $\begin{array}{l}\text { Pulp and paper, cosmetics (treatment of } \\
\text { hyperpigmentation, and skin-lightening through } \\
\text { melanin oxidation), textile, bioremediation } \\
\text { (degradation of azo, heterocyclic, reactive, and } \\
\text { polymeric dyes, xenobiotic, and pesticides), and } \\
\text { bioethanol production }\end{array}$ & [206] \\
\hline
\end{tabular}


Table 2. Cont.

\begin{tabular}{|c|c|c|c|c|c|}
\hline Enzyme & Reaction & Fungi & $\begin{array}{c}\text { Source of } \\
\text { (Isolate) Sample }\end{array}$ & Applications/Potential Uses & Ref. \\
\hline $\begin{array}{l}\text { Lipase } \\
\text { (EC 3.1.1.3) }\end{array}$ & $\begin{array}{l}\text { Hydrolysis of long-chain } \\
\text { triacylglycerol substances } \\
\text { with the formation of an } \\
\text { alcohol and a carboxylic acid }\end{array}$ & $\begin{array}{l}\text { Leucosporidium scottii L117, Metschnikowia } \\
\text { sp. CRM1589; Mrakia blollopis SK-4; } \\
\text { Cystofilobasidium infirmominiatum } \\
\text { 071209-E8-C1-IIa-lev and isolate } \\
\text { 131209-E2A-C1-II-lev; Metschnikowia } \\
\text { australis 131209-E3-C1-(GPY)-lev and } \\
\text { isolate 131209-E2A-C4-II-lev; Rhodotorula } \\
\text { pinicola 071209-E4-C9-lev; Candida } \\
\text { zeylanoides, Cryptococcus victoriae, } \\
\text { Leucosporidiella creatinivora, } \\
\text { Leucosporidium scottii, Candida sake, } \\
\text { Candida spencermartinsiae }\end{array}$ & $\begin{array}{l}\text { Marine sediments; Algal } \\
\text { mat in sediment; marine } \\
\text { sponges: Tedania, } \\
\text { Hymeniacidon, } \\
\text { Dendrilla; Seawater }\end{array}$ & $\begin{array}{l}\text { Food, beverage, detergent, biofuel } \\
\text { production, animal feed, textiles, leather, } \\
\text { paper processing, and cosmetic industry }\end{array}$ & {$[45,47,48,207-209]$} \\
\hline $\begin{array}{l}\text { L-asparaginase } \\
\text { (EC 3.5.1.1) }\end{array}$ & $\begin{array}{l}\text { Degradation of asparagine } \\
\text { into ammonia and aspartate }\end{array}$ & $\begin{array}{c}\text { Cosmospora sp 0B4B, Cosmospora sp 0B1B, } \\
\text { Cosmospora sp 0B2, } \\
\text { Geomyces sp. S2B }\end{array}$ & Marine sediments & $\begin{array}{l}\text { Food industry and medical applications as } \\
\text { anti-cancer, antimicrobial, infectious } \\
\text { diseases, autoimmune diseases }\end{array}$ & [206] \\
\hline $\begin{array}{l}\text { Pectinase } \\
\text { (EC 3.2.1.15) }\end{array}$ & $\begin{array}{l}\text { Hydrolisis of polysaccharides } \\
\text { to produce pectate and } \\
\text { other galacturonans }\end{array}$ & $\begin{array}{l}\text { Geomyces sp. strain F09-T3-2, } \\
\text { Pseudogymnoascus sp., Cladosporium sp. } \\
\text { F09-T12-1, Cryptococcus victoriae, } \\
\text { Leucosporidiella muscorum, Metschnikowia } \\
\text { australis, Rhodotorula glacialis; } \\
\text { Leucosporidiella creatinivora, } \\
\text { Leucosporidium scottii }\end{array}$ & $\begin{array}{l}\text { Marine sponges; marine } \\
\text { sediments; Seawater }\end{array}$ & $\begin{array}{l}\text { Food and textile industry, coffee and tea } \\
\text { fermentation, wine processing, oil extraction, } \\
\text { vegetable and fruit processing industry for } \\
\text { juice clarification, color, and yield enhancer. } \\
\text { Applications in paper and pulp making, } \\
\text { recycling of wastepaper, pretreatment of } \\
\text { pectic wastewaters, and retting of } \\
\text { plant fibers }\end{array}$ & {$[45,82,210]$} \\
\hline $\begin{array}{c}\text { Phytase } \\
\text { (EC 3.1.3.26) }\end{array}$ & $\begin{array}{l}\text { Hydrolysis of phytate to } \\
\text { produce phosphorylated } \\
\text { myo-inositol derivatives }\end{array}$ & Rhodotorula mucilaginosa JMUY14 & Deep-sea sediments & $\begin{array}{l}\text { Food and feed industry, pharmaceutical use } \\
\text { as neuro protective agents, } \\
\text { anti-inflammatory, antioxidant and } \\
\text { anti-cancer agents }\end{array}$ & [211] \\
\hline $\begin{array}{l}\text { Protease } \\
\text { (EC 3.4) }\end{array}$ & Cleavage of peptide bonds & $\begin{array}{l}\text { Rhodotorula mucilaginosa L7; } \\
\text { Pseudogymnoascus sp. CRM1533, } \\
\text { Leucosporidiella muscorum; Leucosporidiella } \\
\text { sp. 131209-E2A-C3-II-lev, Leucosporidiella } \\
\text { creatinivora 071209-E8-C4-II-lev; } \\
\text { Rhodotorula glacialis; Leucosporidiella } \\
\text { creatinivora, Leucosporidium scottii }\end{array}$ & $\begin{array}{c}\text { Marine macroalgae; } \\
\text { marine sediments; marine } \\
\text { sponges: Tedania, } \\
\text { Hymeniacidon; Seawater }\end{array}$ & $\begin{array}{c}\text { Food, feed, pharmacology (anticancer and } \\
\text { antihemolytic activity) cosmetic } \\
\text { (keratin-based preparation) industries, } \\
\text { cleaning processes (e. g. detergent additive), } \\
\text { waste management }\end{array}$ & {$[45,47,48,212,213]$} \\
\hline
\end{tabular}


Table 2. Cont.

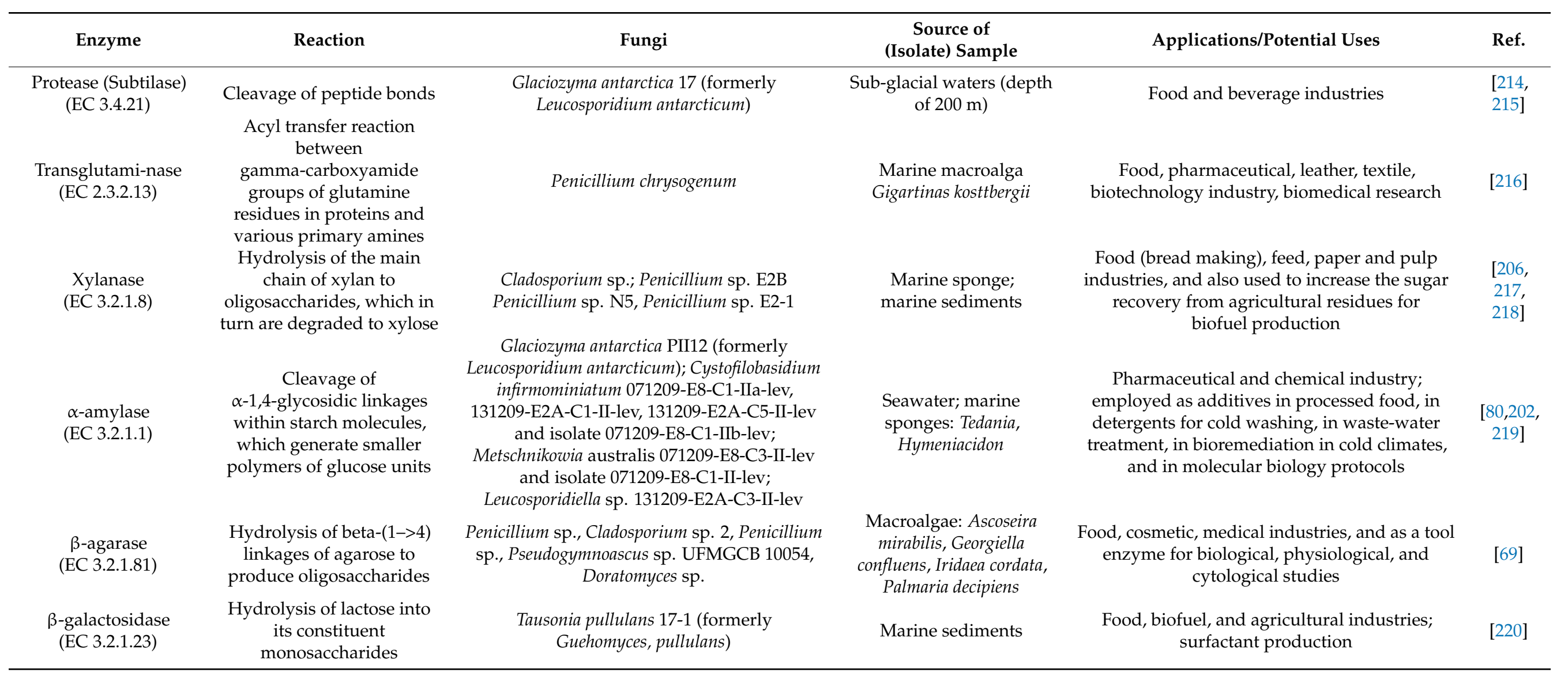


Tausonia pullulans 17-1 isolated from Antarctic marine sediments can produce coldactive $\beta$-galactosidases, which can be a tool for hydrolyzing the lactose present in milk and milk derivatives at low temperatures in the milk-processing industry, allowing intolerant people to consume lactose-free foods and beverages [221,222].

Psychrophilic fungi isolated from Antarctic marine organisms are promising sources of cold-active xylanases, which have interesting applications in the food industry for breadmaking as well as in agricultural industry and biofuel production [206,218,223-225]. For instance, the fungus Cladosporium sp. isolated from a marine sponge displayed high xylanase activity at a lower temperature than the mesophilic fungus Penicillium purpurogenum MYA-30, used as a control [218]. In addition, the Penicillium species isolated from different Antarctic marine organisms (i.e., sea stars, molluscs, macroalgae) were able to produce more than $10 \mathrm{U} \mathrm{mL}^{-1}$ of xylanase molecules after seven days of cultivation at $20.0{ }^{\circ} \mathrm{C}$ [206].

Microbial lipases are important enzymes employed in a variety of applications in the dairy, bakery, oil, meat and fish processing, and beverage industries, for enhancing the food quality, as well as for the detergent and cosmetic industry [226,227]. It is forecasted to reach a market size of 590.2 USD Million by 2023, with an annual growth rate of $6.8 \%$ from 2018 [228]. For example, Lipoclean ${ }^{\circledR}$ marketed by Novozymes is a cold-active lipase that is suitable as a detergent additive for its activity at $\simeq 20{ }^{\circ} \mathrm{C}$, high stability in the presence of other enzymes, at alkaline $\mathrm{pH}$ and also resistance to oxidizing and chelating agents $[229,230]$. An interesting lipase activity was reported in some yeasts belonging to Cryptococcus, Leucosporidium, and Metschnikowia genera, which were isolated from Antarctic marine samples [47]. In particular, the highest activity $\left(0.88 \mathrm{U} \mathrm{mL}^{-1}\right)$ was observed in Metschnikowia sp. CRM 1589 isolated from marine sediments and Salpa sp. when cultured at $15{ }^{\circ} \mathrm{C}$ [47]. At the same temperature Cryptococcus laurentii L59, Cryptococcus adeliensis L121, and Leucosporidium scottii L117 showed an enzyme production between 0.1 and $0.23 \mathrm{U} \mathrm{mL}^{-1}$ after six days of incubation [54]. Generally, yeasts belonging to genera Candida, Yarrowia, and Saccharomyces can produce lipases [231]. In fact, Candida antarctica isolated from sediments of Lake Vanda in Antarctica (a lake permanently covered by ice) can produce two forms of distinct lipases (Lipase A and B), whose production has been patented in 2005 with different industrial and environmental applications [232-234].

Assays using Tween 80 as substrate for testing esterase activity testing identified Cryptococcus, Metschnikowia, Rhodotorula, Leucosporidium, and Leucosporidiella marine genera as cold-active esterase producers [45,208,235]. Hashim et al. (2018) discovered a new cold-active esterase-like protein with putative dienelactone hydrolase (GaDlh) activity produced by the psychrophilic yeast Glaciozyma antarctica isolated from sea ice near the Casey Research Station [205]. This pioneering study on the bioprospection of cold-active enzymes performing the isolation, heterologous expression, and biochemical characterization of recombinant $\mathrm{GaDlh}$ highlighted interesting cold-adapted features in the predicted protein structure at a temperature of $10^{\circ} \mathrm{C}$ and $\mathrm{pH} 8.0$ [205]. Overall, esterase enzymes are exploited in fine chemicals production and pharmaceutical industries for improving the production of optically pure compounds, such as ibuprofen, ketoprofen, and naproxen [236].

Since the beginning of the new millennium, very few studies have addressed the potential of Antarctic marine fungi as protease producers [237]. Proteases account for $60 \%$ of the total enzyme market and it is amongst the most precious commercial enzymes for the wide uses in different kind of industries (i.e., food, pharmacology, detergent) [237-239]. One of the first studies on microbial Antarctic proteases was carried out on Leucosporidium antarcticum 171, which can produce a novel extracellular serine protease, lap2 with an optimal temperature as low as $25^{\circ} \mathrm{C}$, high catalytic efficiency in the range $0-25^{\circ} \mathrm{C}$ [214]. Afterward, halotolerant extracellular protease produced by Rhodotorula mucilaginosa L7 was characterized with optimal catalytic activity at $50{ }^{\circ} \mathrm{C}$ and $\mathrm{pH} 5.0$, after a selection of protease positive strains isolated from marine organisms [54,212]. Recently, Pseudogymnoascus sp. CRM1533, isolated from Antarctic marine sediments, showed a protease activity of 6.21 $\mathrm{U} \mathrm{mL}^{-1}$, even though further studies are needed to characterize the functional potential of this enzyme [47]. The genera Metschnikowia, Cystofilobasidium, and Leucosporidiella, 
associated with Antarctic marine sponges, displayed extracellular amylase between 4 and $20{ }^{\circ} \mathrm{C}$, whereas only Leucosporidiella also showed protease activity [80].

Finally, different fungal genera such as Penicillium, Cladosporium, Geomyces, and Pseudogymnoascus isolated from Antarctic macroalgae and sponges showed carrageenolytic and agarolytic activities which can be useful in processes involving the extraction of the algal biomass for the production of bioethanol $[69,210]$. Among the tested strains, Geomyces sp. strain F09-T3-2 displayed also high activity pectinase: $121 \mathrm{U} / \mathrm{mg}$ after 5 days at $30{ }^{\circ} \mathrm{C}$ [210].

Overall, these findings indicate that the Antarctic marine ecosystems host promising fungal assemblages that display a wide array of unique and novel enzymes. These enzymes offer new horizons for a broad range of biotechnological applications and have great potential to reduce resource and energy consumption, thus promoting eco-sustainability. Obtaining further genetic and functional information on extremophilic fungi inhabiting Antarctic marine ecosystems, coupled with the development of specific bioinformatic pipelines for bioprospecting, are of fundamental importance for the identification of new fungal enzymes and molecules useful for enhancing the growth and competitiveness of the blue biotechnologies.

\subsection{Emerging Bioprospecting Methods: Pitfalls and Future Perspectives}

Isolation techniques usually employed for characterizing extremophilic fungi typically foster isolation of selected fungal taxa (e.g., faster-growing generalists, mesophilic strains), thus hampering our ability of bioprospection of natural molecules produced by the currently unculturable fungi $[32,240,241]$. Indeed, there is evidence that cultivability is a significant bottle-neck for the discovery of natural products from extremophilic marine fungi [242,243]. The implementation and development of methodologies aimed at the isolation of extremophilic fungi are urgently needed to fill this gap [244]. Novel cultivation methods as well as culture-independent approaches, can help to overcome current limitations in our understanding of the fungal biodiversity in extreme environments and in the discovery of new enzymes and molecules with biotechnological potential [245]. Indeed, culture-independent techniques coupled with genomics-based approaches are becoming valuable and fast tools to analyse the functional potential of fungal secondary metabolites useful for biotechnological applications [85,246,247]. Metagenomics, metatranscriptomics, and metaproteomics, as well as single-cell genomics, followed by heterologous expression of selected genes of potential interest, represent promising tools to shed new light on the possible biotechnological exploitation of still-uncultured Antarctic fungi [248-251]. Finally, the bioinformatics mining of the still poorly described but rich genetic biodiversity of Antarctic fungi will certainly enhance the rate of discovery of bioactive molecules potentially useful for biotechnological purposes [30,252].

Supplementary Materials: The following are available online at https:/ /www.mdpi.com/article/10 .3390/jof7050391/s1, Figures S1-S3: Chemical structures of available bioactive compounds; Table S1: Coordinates of different Antarctic samples collected for fungal identification; Table S2: Fungal taxa isolated with culture-dependent methods and identified through metagenomic analyses.

Author Contributions: C.C. and S.V. conceived the study. S.V. and G.B., M.T., E.R., A.D. conducted literature analysis. G.B. performed analyses on the available data. S.V. and G.B. wrote the first draft of the manuscript, and all authors participated in the writing and revision of the manuscript. All authors have read and agreed to the published version of the manuscript.

Funding: This study has been conducted in the framework of the project PNRA16_00173 “Diversity and Evolution of Marine Microbial Communities associated with Antarctic Benthic Invertebrates (DEMBAI)".

Institutional Review Board Statement: Not applicable.

Informed Consent Statement: Not applicable.

Conflicts of Interest: The authors declare that they have no conflict of interest. 


\section{References}

1. Rogers, A.D.; Johnston, N.M.; Murphy, E.J.; Clarke, A. Antarctic Ecosystems; Rogers, A.D., Johnston, N.M., Murphy, E.J., Clarke, A., Eds.; John Wiley \& Sons, Ltd.: Chichester, UK, 2012; ISBN 9781444347241.

2. Chown, S.L.; Brooks, C.M. The State and Future of Antarctic Environments in a Global Context. Annu. Rev. Environ. Resour. 2019, 44, 1-30. [CrossRef]

3. Wall, D.H. Biodiversity and ecosystem functioning in terrestrial habitats of Antarctica. Antarct. Sci. 2005, 17, 523-531. [CrossRef]

4. Peck, L.S. Antarctic marine biodiversity: Adaptations, environments and responses to change. Oceanogr. Mar. Biol. 2018, 56, 105-236.

5. Clarke, A.; Johnston, N. Antarctic Marine Benthic Diversity. In Oceanography and Marine Biology, An Annual Review; CRC Press: Boca Raton, FL, USA, 2003; Volume 41, pp. 55-57.

6. De Broyer, C.; Koubbi, P.; Griffiths, H.J.; Raymond, B.; d'Acoz, C.U.; Van de Putte, A.P.; Danis, B.; David, B.; Grant, S.; Gutt, J.; et al. Biogeographic Atlas of the Southern Ocean; Scientific Committee on Antarctic Research: Cambridge, UK, 2014 ; ISBN 9780948277283.

7. Griffiths, H.J. Antarctic marine biodiversity-What do we know about the distribution of life in the southern ocean? PLoS ONE 2010, 5, e11683. [CrossRef]

8. Gutt, J.; Sirenko, B.I.; Smirnov, I.S.; Arntz, W.E. How many macrozoobenthic species might inhabit the Antarctic shelf? Antarct. Sci. 2004, 16, 11-16. [CrossRef]

9. Gutt, J.; Constable, A.; Cummings, V.; Hosie, G.; McIntyre, T.; Mintenbeck, K.; Murray, A.; Peck, L.; Ropert-Coudert, Y.; Saba, G.K. Vulnerability of Southern Ocean biota to climate change. Antarct. Environ. Portal 2016. [CrossRef]

10. Convey, P.; Peck, L.S. Antarctic environmental change and biological responses. Sci. Adv. 2019, 5, eaaz0888. [CrossRef]

11. Clarke, A.; Crame, J.A. Evolutionary dynamics at high latitudes: Speciation and extinction in polar marine faunas. Philos. Trans. R. Soc. B Biol. Sci. 2010, 365, 3655-3666. [CrossRef]

12. Lo Giudice, A.; Azzaro, M. Diversity and Ecological Roles of Prokaryotes in the Changing Antarctic Marine Environment. In The Ecological Role of Micro-Organisms in the Antarctic Environment; Springer Polar Sciences: Cham, Switzerland; Berlin/Heidelberg, Germany, 2019; pp. 109-131.

13. Cavicchioli, R. Microbial ecology of Antarctic aquatic systems. Nat. Rev. Microbiol. 2015, 13, 691-706. [CrossRef]

14. Worden, A.Z.; Follows, M.J.; Giovannoni, S.J.; Wilken, S.; Zimmerman, A.E.; Keeling, P.J. Rethinking the marine carbon cycle: Factoring in the multifarious lifestyles of microbes. Science 2015, 347, 1257594. [CrossRef]

15. Wilkins, D.; Yau, S.; Williams, T.J.; Allen, M.A.; Brown, M.V.; Demaere, M.Z.; Lauro, F.M.; Cavicchioli, R. Key microbial drivers in Antarctic aquatic environments. FEMS Microbiol. Rev. 2013, 37, 303-335. [CrossRef]

16. Falkowski, P.G.; Fenchel, T.; Delong, E.F. The microbial engines that drive Earth's biogeochemical cycles. Science 2008, 320, 1034-1039. [CrossRef]

17. Margesin, R.; Feller, G. Biotechnological applications of psychrophiles. Environ. Technol. 2010, 31, 835-844. [CrossRef]

18. Rizzo, C.; Lo Giudice, A. The variety and inscrutability of polar environments as a resource of biotechnologically relevant molecules. Microorganisms 2020, 8, 1422. [CrossRef]

19. Correa, T.; Abreu, F. Antarctic microorganisms as sources of biotechnological products. In Physiological and Biotechnological Aspects of Extremophiles; Salwan, R., Sharma, V., Eds.; Elsevier: Amsterdam, The Netherlands, 2020; pp. 269-284. ISBN 978-0-12-818322-9.

20. Bruno, S.; Coppola, D.; di Prisco, G.; Giordano, D.; Verde, C. Enzymes from Marine Polar Regions and Their Biotechnological Applications. Mar. Drugs 2019, 17, 544. [CrossRef]

21. Tiquia-Arashiro, S.M.; Grube, M. Fungi in Extreme Environments: Ecological Role and Biotechnological Significance; Tiquia-Arashiro, S.M., Grube, M., Eds.; Springer International Publishing: Cham, Switzerland; Berlin/Heidelberg, Germany, 2019; ISBN 978-3-03019030-9.

22. Sayed, A.M.M.; Hassan, M.H.A.H.A.; Alhadrami, H.A.A.; Hassan, H.M.M.; Goodfellow, M.; Rateb, M.E.E. Extreme environments: Microbiology leading to specialized metabolites. J. Appl. Microbiol. 2020, 128, 630-657. [CrossRef]

23. Macheleidt, J.; Mattern, D.J.; Fischer, J.; Netzker, T.; Weber, J.; Schroeckh, V.; Valiante, V.; Brakhage, A.A. Regulation and role of fungal secondary metabolites. Annu. Rev. Genet. 2016, 50, 371-392. [CrossRef]

24. Spiteller, P. Chemical ecology of fungi. Nat. Prod. Rep. 2015, 32, 971-993. [CrossRef]

25. Brakhage, A.A. Regulation of fungal secondary metabolism. Nat. Rev. Microbiol. 2013, 11, 21-32. [CrossRef]

26. Yu, J.-H.; Keller, N. Regulation of secondary metabolism in filamentous fungi. Annu. Rev. Phytopathol. 2005, 43, 437-458. [CrossRef]

27. Rosa, L.H. Fungi of Antarctica: Diversity, Ecology and Biotechnological Applications; Springer International Publishing: Cham, Switzerland; Berlin/Heidelberg, Germany, 2019; ISBN 978-3-030-18367-7.

28. Yarzábal, L.A. Antarctic Psychrophilic Microorganisms and Biotechnology: History, Current Trends, Applications, and Challenges. In Microbial Models: From Environmental to Industrial Sustainability; Springer: Singapore, 2016; pp. 83-118.

29. Corinaldesi, C.; Barone, G.; Marcellini, F.; Dell'Anno, A.; Danovaro, R. Marine microbial-derived molecules and their potential use in cosmeceutical and cosmetic products. Mar. Drugs 2017, 15, 118. [CrossRef]

30. Chávez, R.; Fierro, F.; García-Rico, R.O.; Vaca, I. Filamentous fungi from extreme environments as a promising source of novel bioactive secondary metabolites. Front. Microbiol. 2015, 6, 903. [CrossRef] [PubMed]

31. Cavicchioli, R.; Amils, R.; Wagner, D.; Mcgenity, T. Life and applications of extremophiles. Environ. Microbiol. 2011, 13, 1903-1907. [CrossRef] [PubMed] 
32. Amend, A.; Burgaud, G.; Cunliffe, M.; Edgcomb, V.P.; Ettinger, C.L.; Gutiérrez, M.H.; Heitman, J.; Hom, E.F.Y.; Ianiri, G.; Jones, A.C.; et al. Fungi in the marine environment: Open questions and unsolved problems. MBio 2019, 10, 2021. [CrossRef] [PubMed]

33. Wang, Y.; Sen, B.; He, Y.; Xie, N.; Wang, G. Spatiotemporal Distribution and Assemblages of Planktonic Fungi in the Coastal Waters of the Bohai Sea. Front. Microbiol. 2018, 9, 584. [CrossRef] [PubMed]

34. Hassett, B.T.; Vonnahme, T.R.; Peng, X.; Jones, E.B.G.; Heuzé, C. Global diversity and geography of planktonic marine fungi. Bot. Mar. 2020, 63, 121-139. [CrossRef]

35. López-García, P.; Rodríguez-Valera, F.; Pedrós-Alió, C.; Moreira, D. Unexpected diversity of small eukaryotes in deep-sea Antarctic plankton. Nature 2001, 409, 603-607. [CrossRef]

36. Zhang, T.; Wang, N.F.; Zhang, Y.Q.; Liu, H.Y.; Yu, L.Y. Diversity and distribution of fungal communities in the marine sediments of Kongsfjorden, Svalbard (High Arctic). Sci. Rep. 2015, 5, 14524. [CrossRef]

37. Hassett, B.T.; Ducluzeau, A.L.L.; Collins, R.E.; Gradinger, R. Spatial distribution of aquatic marine fungi across the western Arctic and sub-arctic. Environ. Microbiol. 2017, 19, 475-484. [CrossRef]

38. Turkiewicz, M.; Pazgier, M.; Donachie, S.P.; Kalinowska, H. Invertase and $\alpha$-glucosidase production by the endemic Antarctic marine yeast Leucosporidium antarcticum. Polish Polar Res. 2005, 26, 125-136.

39. Gonçalves, V.N.; Vitoreli, G.A.; de Menezes, G.C.A.; Mendes, C.R.B.; Secchi, E.R.; Rosa, C.A.; Rosa, L.H. Taxonomy, phylogeny and ecology of cultivable fungi present in seawater gradients across the Northern Antarctica Peninsula. Extremophiles 2017, 21, 1005-1015. [CrossRef]

40. Ward, N.A.; Robertson, C.L.; Chanda, A.K.; Schneider, R.W. Effects of Simplicillium lanosoniveum on phakopsora pachyrhizi, the soybean rust pathogen, and its use as a biological control agent. Phytopathology 2012, 102, 749-760. [CrossRef]

41. Guerra, R.S.; do Nascimento, M.M.F.; Miesch, S.; Najafzadeh, M.J.; Ribeiro, R.O.; Ostrensky, A.; de Hoog, G.S.; Vicente, V.A.; Boeger, W.A. Black Yeast Biota in the Mangrove, in Search of the Origin of the Lethargic Crab Disease (LCD). Mycopathologia 2013, 175, 421-430. [CrossRef]

42. Dayarathne, M.; Jones, E.; Maharachchikumbura, S.; Devadatha, B.; Sarma, V.; Khongphinitbunjong, K.; Chomnunti, P.; Hyde, K. Morpho-molecular characterization of microfungi associated with marine based habitats. Mycosphere 2020, 11, 1-188. [CrossRef]

43. Hassett, B.T.; Gradinger, R. Chytrids dominate arctic marine fungal communities. Environ. Microbiol. 2016, 18, 2001-2009. [CrossRef]

44. Hassett, B.T.; Borrego, E.J.; Vonnahme, T.R.; Rämä, T.; Kolomiets, M.V.; Gradinger, R. Arctic marine fungi: Biomass, functional genes, and putative ecological roles. ISME J. 2019, 13, 1484-1496. [CrossRef]

45. Vaz, A.B.M.; Rosa, L.H.; Vieira, M.L.A.; de Garcia, V.; Brandão, L.R.; Teixeira, L.C.R.S.; Moliné, M.; Libkind, D.; van Broock, M.; Rosa, C.A. The diversity, extracellular enzymatic activities and photoprotective compounds of yeasts isolated in Antarctica. Braz. J. Microbiol. 2011, 42, 937-947. [CrossRef]

46. Wu, G.; Ma, H.; Zhu, T.; Li, J.; Gu, Q.; Li, D. Penilactones A and B, two novel polyketides from Antarctic deep-sea derived fungus Penicillium crustosum PRB-2. Tetrahedron 2012, 68, 9745-9749. [CrossRef]

47. Wentzel, L.C.P.; Inforsato, F.J.; Montoya, Q.V.; Rossin, B.G.; Nascimento, N.R.; Rodrigues, A.; Sette, L.D. Fungi from Admiralty Bay (King George Island, Antarctica) Soils and Marine Sediments. Microb. Ecol. 2019, 77, 12-24. [CrossRef]

48. Ogaki, M.B.; Teixeira, D.R.; Vieira, R.; Lírio, J.M.; Felizardo, J.P.S.; Abuchacra, R.C.; Cardoso, R.P.; Zani, C.L.; Alves, T.M.A.; Junior, P.A.S.; et al. Diversity and bioprospecting of cultivable fungal assemblages in sediments of lakes in the Antarctic Peninsula. Extremophiles 2020, 124, 601-611. [CrossRef]

49. Ogaki, M.B.; Pinto, O.H.B.; Vieira, R.; Neto, A.A.; Convey, P.; Carvalho-Silva, M.; Rosa, C.A.; Câmara, P.E.A.S.; Rosa, L.H. Fungi Present in Antarctic Deep-Sea Sediments Assessed Using DNA Metabarcoding. Microb. Ecol. 2021, 1-8. [CrossRef]

50. Ha, T.M.; Kim, D.-C.C.; Sohn, J.H.; Yim, J.H.; Oh, H. Anti-Inflammatory and Protein Tyrosine Phosphatase 1B Inhibitory Metabolites from the Antarctic Marine-Derived Fungal Strain Penicillium glabrum SF-7123. Mar. Drugs 2020, 18, 247. [CrossRef] [PubMed]

51. Wu, G.; Lin, A.; Gu, Q.; Zhu, T.; Li, D. Four new chloro-eremophilane sesquiterpenes from an antarctic deep-sea derived fungus, Penicillium sp. PR19N-1. Mar. Drugs 2013, 11, 1399-1408. [CrossRef] [PubMed]

52. Niu, S.; Fan, Z.-W.; Xie, C.-L.; Liu, Q.; Luo, Z.-H.; Liu, G.; Yang, X.-W. Spirograterpene A, a Tetracyclic Spiro-Diterpene with a Fused 5/5/5/5 Ring System from the Deep-Sea-Derived Fungus Penicillium granulatum MCCC 3A00475. J. Nat. Prod. 2017, 80, 2174-2177. [CrossRef]

53. Laich, F.; Vaca, I.; Chávez, R. Rhodotorula portillonensis sp. nov., a basidiomycetous yeast isolated from Antarctic shallow-water marine sediment. Int. J. Syst. Evol. Microbiol. 2013, 63, 3884-3891. [CrossRef]

54. Duarte, A.W.F.; Dayo-Owoyemi, I.; Nobre, F.S.; Pagnocca, F.C.; Chaud, L.C.S.; Pessoa, A.; Felipe, M.G.A.; Sette, L.D. Taxonomic assessment and enzymes production by yeasts isolated from marine and terrestrial Antarctic samples. Extremophiles 2013, 17, 1023-1035. [CrossRef]

55. Gonçalves, V.N.; Campos, L.S.; Melo, I.S.; Pellizari, V.H.; Rosa, C.A.; Rosa, L.H. Penicillium solitum: A mesophilic, psychrotolerant fungus present in marine sediments from Antarctica. Polar Biol. 2013, 36, 1823-1831. [CrossRef]

56. Ren, J.; Yang, Y.; Liu, D.; Chen, W.; Proksch, P.; Shao, B.; Lin, W. Sequential determination of new peptaibols asperelines G-Z12 produced by marine-derived fungus Trichoderma asperellum using ultrahigh pressure liquid chromatography combined with electrospray-ionization tandem mass spectrometry. J. Chromatogr. A 2013, 1309, 90-95. [CrossRef] 
57. Purić, J.; Vieira, G.; Cavalca, L.B.B.; Sette, L.D.D.; Ferreira, H.; Vieira, M.L.C.L.C.; Sass, D.C.C. Activity of Antarctic fungi extracts against phytopathogenic bacteria. Lett. Appl. Microbiol. 2018, 66, 530-536. [CrossRef]

58. Vieira, G.; Purić, J.; Morão, L.G.G.; dos Santos, J.A.A.; Inforsato, F.J.J.; Sette, L.D.D.; Ferreira, H.; Sass, D.C.C. Terrestrial and marine Antarctic fungi extracts active against Xanthomonas citri subsp. citri. Lett. Appl. Microbiol. 2018, 67, 64-71. [CrossRef]

59. Li, W.; Luo, D.; Huang, J.; Wang, L.; Zhang, F.; Xi, T.; Liao, J.; Lu, Y. Antibacterial constituents from Antarctic fungus, Aspergillus sydowii SP-1. Nat. Prod. Res. 2018, 32, 662-667. [CrossRef]

60. Zhou, Y.; Li, Y.H.; Yu, H.B.; Liu, X.Y.; Lu, X.L.; Jiao, B.H. Furanone derivative and sesquiterpene from Antarctic marine-derived fungus Penicillium sp. S-1-18. J. Asian Nat. Prod. Res. 2018, 20, 1108-1115. [CrossRef]

61. Liu, C.-C.; Zhang, Z.-Z.; Feng, Y.-Y.; Gu, Q.-Q.; Li, D.-H.; Zhu, T.-J. Secondary metabolites from Antarctic marine-derived fungus Penicillium crustosum HDN153086. Nat. Prod. Res. 2019, 33, 414-419. [CrossRef]

62. Mercantini, R.; Marsella, R.; Moretto, D.; Finotti, E. Keratinophilic fungi in the antarctic environment. Mycopathologia 1993, 122, 169-175. [CrossRef]

63. Dos Santos, J.A.; Meyer, E.; Sette, L.D. Fungal community in antarctic soil along the retreating collins glacier (Fildes peninsula, King George Island). Microorganisms 2020, 8, 1145. [CrossRef]

64. Loque, C.P.; Medeiros, A.O.; Pellizzari, F.M.; Oliveira, E.C.; Rosa, C.A.; Rosa, L.H. Fungal community associated with marine macroalgae from Antarctica. Polar Biol. 2010, 33, 641-648. [CrossRef]

65. Putzke, J.; Pereira, A.B.; Pereira, A.B. Phaeosphaeria deschampsii (Ascomycota): A new parasite species of Deschampsia antarctica (Poaceae) described to Antarctica. An. Acad. Bras. Cienc. 2016, 88, 1967-1969. [CrossRef]

66. Godinho, V.M.; Furbino, L.E.; Santiago, I.F.; Pellizzari, F.M.; Yokoya, N.S.; Pupo, D.; Alves, T.M.A.; Junior, P.A.S.; Romanha, A.J.; Zani, C.L.; et al. Diversity and bioprospecting of fungal communities associated with endemic and cold-adapted macroalgae in Antarctica. ISME J. 2013, 7, 1434-1451. [CrossRef]

67. Fernandes Duarte, A.W.; Zambrano Passarini, M.R.; Delforno, T.P.; Pellizzari, F.M.; Zecchin Cipro, C.V.; Montone, R.C.; Petry, M.V.; Putzke, J.; Rosa, L.H.; Sette, L.D. Yeasts from macroalgae and lichens that inhabit the South Shetland Islands, Antarctica. Environ. Microbiol. Rep. 2016, 8, 874-885. [CrossRef]

68. Furbino, L.E.; Godinho, V.M.; Santiago, I.F.; Pellizari, F.M.; Alves, T.M.A.A.; Zani, C.L.; Junior, P.A.S.S.; Romanha, A.J.; Carvalho, A.G.O.O.; Gil, L.H.V.G.V.G.; et al. Diversity Patterns, Ecology and Biological Activities of Fungal Communities Associated with the Endemic Macroalgae Across the Antarctic Peninsula. Microb. Ecol. 2014, 67, 775-787. [CrossRef]

69. Furbino, L.E.; Pellizzari, F.M.; Neto, P.C.; Rosa, C.A.; Rosa, L.H. Isolation of fungi associated with macroalgae from maritime Antarctica and their production of agarolytic and carrageenolytic activities. Polar Biol. 2018, 41, 527-535. [CrossRef]

70. Martorell, M.M.; Lannert, M.; Matula, C.V.; Quartino, M.L.; de Figueroa, L.I.C.; Mac Cormack, W.P.; Ruberto, L.A.M. Studies toward the comprehension of fungal-macroalgae interaction in cold marine regions from a biotechnological perspective. Fungal Biol. 2020, 125, 218-230. [CrossRef]

71. Alker, A.P.; Smith, G.W.; Kim, K. Characterization of Aspergillus sydowii (Thom et Church), a fungal pathogen of Caribbean sea fan corals. Hydrobiologia 2001, 460, 105-111. [CrossRef]

72. Van Dover, C.L.; Ward, M.E.; Scott, J.L.; Underdown, J.; Anderson, B.; Gustafson, C.; Whalen, M.; Carnegie, R.B. A fungal epizootic in mussels at a deep-sea hydrothermal vent. Mar. Ecol. 2007, 28, 54-62. [CrossRef]

73. Cawthorn, R.J. Diseases of American lobsters (Homarus americanus): A review. J. Invertebr. Pathol. 2011, 106, 71-78. [CrossRef]

74. Amend, A. From Dandruff to Deep-Sea Vents: Malassezia-like Fungi Are Ecologically Hyper-diverse. PLoS Pathog. 2014, 10, e1004277. [CrossRef]

75. Nagahama, T.; Hamamoto, M.; Nakase, T.; Horikoshi, K. Rhodotorula lamellibrachii sp. nov., a new yeast species from a tubeworm collected at the deep-sea floor in Sagami Bay and its phylogenetic analysis. Antonie Leeuwenhoek 2001, 80, 317-323. [CrossRef]

76. Yu, Z.; Zhang, B.; Sun, W.; Zhang, F.; Li, Z. Phylogenetically diverse endozoic fungi in the South China Sea sponges and their potential in synthesizing bioactive natural products suggested by PKS gene and cytotoxic activity analysis. Fungal Divers. 2013, 58, 127-141. [CrossRef]

77. Nguyen, M.T.H.D.; Thomas, T. Diversity, host-specificity and stability of sponge-associated fungal communities of co-occurring sponges. PeerJ 2018, 2018, e4965. [CrossRef] [PubMed]

78. Raghukumar, S. Animals in Coastal Benthic Ecosystem and Aquaculture Systems. In Fungi in Coastal and Oceanic Marine Ecosystems; Raghukumar, S., Ed.; Springer International Publishing: Cham, Switzerland; Berlin/Heidelberg, Germany, 2017; pp. 163-183. ISBN 978-3-319-54304-8.

79. Laich, F.; Chávez, R.; Vaca, I. Leucosporidium escuderoi f.a., sp. nov., a basidiomycetous yeast associated with an Antarctic marine sponge. Antonie Leeuwenhoek 2014, 105, 593-601. [CrossRef] [PubMed]

80. Vaca, I.; Faúndez, C.; Maza, F.; Paillavil, B.; Hernández, V.; Acosta, F.; Levicán, G.; Martínez, C.; Chávez, R. Cultivable psychrotolerant yeasts associated with Antarctic marine sponges. World J. Microbiol. Biotechnol. 2013, 29, 183-189. [CrossRef]

81. Kim, D.C.; Lee, H.S.; Ko, W.; Lee, D.S.; Sohn, J.H.; Yim, J.H.; Kim, Y.C.; Oh, H. Anti-inflammatory effect of methylpenicinoline from a marine isolate of Penicillium sp. (SF-5995): Inhibition of NF- $\mathrm{KB}$ and MAPK pathways in lipopolysaccharide-induced RAW264.7 macrophages and BV2 microglia. Molecules 2014, 19, 18073-18089. [CrossRef]

82. Henríquez, M.; Vergara, K.; Norambuena, J.; Beiza, A.; Maza, F.; Ubilla, P.; Araya, I.; Chávez, R.; San-Martín, A.; Darias, J.; et al Diversity of cultivable fungi associated with Antarctic marine sponges and screening for their antimicrobial, antitumoral and antioxidant potential. World J. Microbiol. Biotechnol. 2014, 30, 65-76. [CrossRef] 
83. Cui, X.; Zhu, G.; Liu, H.; Jiang, G.; Wang, Y.; Zhu, W. Diversity and function of the Antarctic krill microorganisms from Euphausia superba. Sci. Rep. 2016, 6, 36496. [CrossRef]

84. Wang, F.; Sheng, J.; Chen, Y.; Xu, J. Microbial diversity and dominant bacteria causing spoilage during storage and processing of the Antarctic krill, Euphausia superba. Polar Biol. 2021, 44, 163-171. [CrossRef]

85. Moreno-Pino, M.; Cristi, A.; Gillooly, J.F.; Trefault, N. Characterizing the microbiomes of Antarctic sponges: A functional metagenomic approach. Sci. Rep. 2020, 10, 645. [CrossRef]

86. Coda, R.; Cassone, A.; Rizzello, C.G.; Nionelli, L.; Cardinali, G.; Gobbetti, M. Antifungal activity of Wickerhamomyces anomalus and Lactobacillus plantarum during sourdough fermentation: Identification of novel compounds and long-term effect during storage of wheat bread. Appl. Environ. Microbiol. 2011, 77, 3484-3492. [CrossRef]

87. Walker, A.K.; Robicheau, B.M. Fungal diversity and community structure from coastal and barrier island beaches in the United States Gulf of Mexico. Sci. Rep. 2021, 11, 3889. [CrossRef]

88. Nagano, Y.; Nagahama, T.; Hatada, Y.; Nunoura, T.; Takami, H.; Miyazaki, J.; Takai, K.; Horikoshi, K. Fungal diversity in deep-sea sediments-The presence of novel fungal groups. Fungal Ecol. 2010, 3, 316-325. [CrossRef]

89. Rédou, V.; Ciobanu, M.C.; Pachiadaki, M.G.; Edgcomb, V.; Alain, K.; Barbier, G.; Burgaud, G. In-depth analyses of deep subsurface sediments using 454-pyrosequencing reveals a reservoir of buried fungal communities at record-breaking depths. FEMS Microbiol. Ecol. 2014, 90, 908-921. [CrossRef]

90. Singh, P.; Raghukumar, C.; Verma, P.; Shouche, Y. Fungal Community Analysis in the Deep-Sea Sediments of the Central Indian Basin by Culture-Independent Approach. Microb. Ecol. 2011, 61, 507-517. [CrossRef]

91. Gao, Y.; Du, X.; Xu, W.; Fan, R.; Zhang, X.; Yang, S.; Chen, X.; Lv, J.; Luo, Z. Fungal Diversity in Deep Sea Sediments from East Yap Trench and Their Denitrification Potential. Geomicrobiol. J. 2020, 37, 848-858. [CrossRef]

92. Vargas-Gastélum, L.; Riquelme, M. The Mycobiota of the Deep Sea: What Omics Can Offer. Life 2020, 10, 292. [CrossRef]

93. Barone, G.; Rastelli, E.; Corinaldesi, C.; Tangherlini, M.; Danovaro, R.; Dell'Anno, A. Benthic deep-sea fungi in submarine canyons of the Mediterranean Sea. Prog. Oceanogr. 2018, 168, 57-64. [CrossRef]

94. Yang, S.; Xu, W.; Gao, Y.; Chen, X.; Luo, Z.H. Fungal diversity in deep-sea sediments from Magellan seamounts environment of the western Pacific revealed by high-throughput Illumina sequencing. J. Microbiol. 2020, 58, 841-852. [CrossRef]

95. Alexander, E.; Stock, A.; Breiner, H.W.; Behnke, A.; Bunge, J.; Yakimov, M.M.; Stoeck, T. Microbial eukaryotes in the hypersaline anoxic L'Atalante deep-sea basin. Environ. Microbiol. 2009, 11, 360-381. [CrossRef]

96. Bernhard, J.M.; Kormas, K.; Pachiadaki, M.G.; Rocke, E.; Beaudoin, D.J.; Morrison, C.; Visscher, P.T.; Cobban, A.; Starczak, V.R.; Edgcomb, V.P. Benthic protists and fungi of Mediterranean deep hypsersaline anoxic basin redoxcline sediments. Front. Microbiol. 2014, 5, 605. [CrossRef]

97. Stock, A.; Breiner, H.W.; Pachiadaki, M.; Edgcomb, V.; Filker, S.; La Cono, V.; Yakimov, M.M.; Stoeck, T. Microbial eukaryote life in the new hypersaline deep-sea basin Thetis. Extremophiles 2012, 16, 21-34. [CrossRef]

98. Nagahama, T.; Takahashi, E.; Nagano, Y.; Abdel-Wahab, M.A.; Miyazaki, M. Molecular evidence that deep-branching fungi are major fungal components in deep-sea methane cold-seep sediments. Environ. Microbiol. 2011, 13, 2359-2370. [CrossRef]

99. Wang, Y.; Zhang, W.P.; Cao, H.L.; Shek, C.S.; Tian, R.M.; Wong, Y.H.; Batang, Z.; Al-Suwailem, A.; Qian, P.-Y.Y. Diversity and distribution of eukaryotic microbes in and around a brine pool adjacent to the Thuwal cold seeps in the Red Sea. Front. Microbiol. 2014, 5, 37. [CrossRef]

100. Nagano, Y.; Miura, T.; Nishi, S.; Lima, A.O.; Nakayama, C.; Pellizari, V.H.; Fujikura, K. Fungal diversity in deep-sea sediments associated with asphalt seeps at the Sao Paulo Plateau. Deep Sea Res. Part II Top. Stud. Oceanogr. 2017, 146, 59-67. [CrossRef]

101. Gadanho, M.; Sampaio, J.P. Occurrence and diversity of yeasts in the mid-atlantic ridge hydrothermal fields near the Azores Archipelago. Microb. Ecol. 2005, 50, 408-417. [CrossRef] [PubMed]

102. Burgaud, G.; Arzur, D.; Durand, L.; Cambon-Bonavita, M.-A.; Barbier, G. Marine culturable yeasts in deep-sea hydrothermal vents: Species richness and association with fauna. FEMS Microbiol. Ecol. 2010, 73, 121-133. [CrossRef] [PubMed]

103. Velez, P.; Gasca-Pineda, J.; Riquelme, M. Cultivable fungi from deep-sea oil reserves in the Gulf of Mexico: Genetic signatures in response to hydrocarbons. Mar. Environ. Res. 2020, 153, 104816. [CrossRef] [PubMed]

104. Gonçalves, V.N.; Carvalho, C.R.; Johann, S.; Mendes, G.; Alves, T.M.; Zani, C.L.; Junior, P.A.S.S.; Murta, S.M.F.F.; Romanha, A.J.; Cantrell, C.L.; et al. Antibacterial, antifungal and antiprotozoal activities of fungal communities present in different substrates from Antarctica. Polar Biol. 2015, 38, 1143-1152. [CrossRef]

105. Bochdansky, A.B.; Clouse, M.A.; Herndl, G.J. Eukaryotic microbes, principally fungi and labyrinthulomycetes, dominate biomass on bathypelagic marine snow. ISME J. 2017, 11, 362-373. [CrossRef]

106. Ogaki, M.B.; Coelho, L.C.; Vieira, R.; Neto, A.A.; Zani, C.L.; Alves, T.M.A.A.; Junior, P.A.S.S.; Murta, S.M.F.F.; Barbosa, E.C.; Oliveira, J.G.; et al. Cultivable fungi present in deep-sea sediments of Antarctica: Taxonomy, diversity, and bioprospecting of bioactive compounds. Extremophiles 2020, 24, 227-238. [CrossRef]

107. Gladfelter, A.S.; James, T.Y.; Amend, A.S. Marine fungi. Curr. Biol. 2019, 29, R191-R195. [CrossRef]

108. Harms, H.; Schlosser, D.; Wick, L.Y. Untapped potential: Exploiting fungi in bioremediation of hazardous chemicals. Nat. Rev. Microbiol. 2011, 9, 177-192. [CrossRef]

109. Barone, G.; Varrella, S.; Tangherlini, M.; Rastelli, E.; Dell'Anno, A.; Danovaro, R.; Corinaldesi, C.; Dell'Anno, A.; Danovaro, R.; Corinaldesi, C. Marine Fungi: Biotechnological Perspectives from Deep-Hypersaline Anoxic Basins. Diversity 2019, 11, 113. [CrossRef] 
110. Grossart, H.P.; Rojas-Jimenez, K. Aquatic fungi: Targeting the forgotten in microbial ecology. Curr. Opin. Microbiol. 2016, 31, 140-145. [CrossRef]

111. Taylor, J.D.; Cunliffe, M. Multi-year assessment of coastal planktonic fungi reveals environmental drivers of diversity and abundance. ISME J. 2016, 10, 2118-2128. [CrossRef]

112. Grossart, H.P.; Van den Wyngaert, S.; Kagami, M.; Wurzbacher, C.; Cunliffe, M.; Rojas-Jimenez, K. Fungi in aquatic ecosystems. Nat. Rev. Microbiol. 2019, 17, 339-354. [CrossRef]

113. Kagami, M.; Miki, T.; Takimoto, G. Mycoloop: Chytrids in aquatic food webs. Front. Microbiol. 2014, 5, 166. [CrossRef]

114. Comeau, A.M.; Vincent, W.F.; Bernier, L.; Lovejoy, C. Novel chytrid lineages dominate fungal sequences in diverse marine and freshwater habitats. Sci. Rep. 2016, 6, 30120. [CrossRef]

115. De Vargas, C.; Audic, S.; Henry, N.; Decelle, J.; Mahé, F.; Logares, R.; Lara, E.; Berney, C.; Le Bescot, N.; Probert, I.; et al. Eukaryotic plankton diversity in the sunlit ocean. Science 2015, 15, 1261605. [CrossRef]

116. Frenken, T.; Alacid, E.; Berger, S.A.; Bourne, E.C.; Gerphagnon, M.; Grossart, H.P.; Gsell, A.S.; Ibelings, B.W.; Kagami, M.; Küpper, F.C.; et al. Integrating chytrid fungal parasites into plankton ecology: Research gaps and needs. Environ. Microbiol. 2017, 19, 3802-3822. [CrossRef]

117. Lepelletier, F.; Karpov, S.A.; Alacid, E.; Le Panse, S.; Bigeard, E.; Garcés, E.; Jeanthon, C.; Guillou, L. Dinomyces arenysensis gen. et sp. nov. (Rhizophydiales, Dinomycetaceae fam. nov.), a Chytrid Infecting Marine Dinoflagellates. Protist 2014, 165, 230-244. [CrossRef]

118. Sime-Ngando, T. Phytoplankton Chytridiomycosis: Fungal Parasites of Phytoplankton and Their Imprints on the Food Web Dynamics. Front. Microbiol. 2012, 3, 361. [CrossRef]

119. Scholz, B.; Küpper, F.C.; Vyverman, W.; Karsten, U. Eukaryotic pathogens (Chytridiomycota and Oomycota) infecting marine microphytobenthic diatoms-A methodological comparison. J. Phycol. 2014, 50, 1009-1019. [CrossRef]

120. Gleason, F.H.; Kagami, M.; Lefevre, E.; Sime-Ngando, T. The ecology of chytrids in aquatic ecosystems: Roles in food web dynamics. Fungal Biol. Rev. 2008, 22, 17-25. [CrossRef]

121. Gachon, C.M.M.; Sime-Ngando, T.; Strittmatter, M.; Chambouvet, A.; Kim, G.H. Algal diseases: Spotlight on a black box. Trends Plant Sci. 2010, 15, 633-640. [CrossRef]

122. Pusceddu, A.; Dell'Anno, A.; Fabiano, M.; Danovaro, R. Quantity and bioavailability of sediment organic matter as signatures of benthic trophic status. Mar. Ecol. Prog. Ser. 2009, 375, 41-52. [CrossRef]

123. Jebaraj, C.S.; Raghukumar, C.; Behnke, A.; Stoeck, T. Fungal diversity in oxygen-depleted regions of the Arabian Sea revealed by targeted environmental sequencing combined with cultivation. FEMS Microbiol. Ecol. 2010, 71, 399-412. [CrossRef] [PubMed]

124. Dethier, M.N.; Brown, A.S.; Burgess, S.; Eisenlord, M.E.; Galloway, A.W.E.; Kimber, J.; Lowe, A.T.; O’Neil, C.M.; Raymond, W.W.; Sosik, E.A.; et al. Degrading detritus: Changes in food quality of aging kelp tissue varies with species. J. Exp. Mar. Bio. Ecol. 2014, 460, 72-79. [CrossRef]

125. Crowther, T.W.; Grossart, H.P. The role of bottom-up and top-down interactions in determining microbial and fungal diversity and function. In Trophic Ecology: Bottom-Up and Top-Down Interactions Across Aquatic and Terrestrial Systems; Hanley, T.C., La Pierre, K.J., Eds.; Cambridge University Press: Cambridge, UK, 2015; pp. 260-287. ISBN 9781139924856.

126. Attermeyer, K.; Premke, K.; Hornick, T.; Hilt, S.; Grossart, H.P. Ecosystem-level studies of terrestrial carbon reveal contrasting bacterial metabolism in different aquatic habitats. Ecology 2013, 94, 2754-2766. [CrossRef] [PubMed]

127. Gomes, F.C.O.; Safar, S.V.B.; Marques, A.R.; Medeiros, A.O.; Santos, A.R.O.; Carvalho, C.; Lachance, M.-A.; Sampaio, J.P.; Rosa, C.A. The diversity and extracellular enzymatic activities of yeasts isolated from water tanks of Vriesea minarum, an endangered bromeliad species in Brazil, and the description of Occultifur brasiliensis f.a., sp. nov. Antonie Leeuwenhoek 2015, 107, 597-611. [CrossRef] [PubMed]

128. Krauss, G.J.; Solé, M.; Krauss, G.; Schlosser, D.; Wesenberg, D.; Bärlocher, F. Fungi in freshwaters: Ecology, physiology and biochemical potential. FEMS Microbiol. Rev. 2011, 35, 620-651. [CrossRef]

129. Bhadury, P.; Bik, H.; Lambshead, J.D.; Austen, M.C.; Smerdon, G.R.; Rogers, A.D. Molecular diversity of fungal phylotypes Co-Amplified alongside nematodes from coastal and Deep-Sea marine environments. PLoS ONE 2011, 6, e26445. [CrossRef]

130. Sapir, A.; Dillman, A.R.; Connon, S.A.; Grupe, B.M.; Ingels, J.; Mundo-Ocampo, M.; Levin, L.A.; Baldwin, J.G.; Orphan, V.J.; Sternberg, P.W. Microsporidia-nematode associations in methane seeps reveal basal fungal parasitism in the deep sea. Front. Microbiol. 2014, 5, 43. [CrossRef]

131. Dayton, P.K. Ecology of Kelp Communities. Annu. Rev. Ecol. Syst. 1985, 16, 215-245. [CrossRef]

132. Rateb, M.E.; Ebel, R. Secondary metabolites of fungi from marine habitats. Nat. Prod. Rep. 2011, 28, 290-344. [CrossRef]

133. Jones, E.B.G.; Pang, K.-L. Marine Fungi: And Fungal-Like Organisms; Walter de Gruyter: Berlin, Germany, $2012 ;$ ISBN 3110264064.

134. Richards, T.A.; Jones, M.D.M.; Leonard, G.; Bass, D. Marine fungi: Their ecology and molecular diversity. Ann. Rev. Mar. Sci. 2012, 4, 495-522. [CrossRef]

135. Zuccaro, A.; Mitchell, J.I. Fungal communities of seaweeds. In The Fungal Community; CRC Press: Boca Raton, USA, 2005; pp. 533-579.

136. Egan, S.; Harder, T.; Burke, C.; Steinberg, P.; Kjelleberg, S.; Thomas, T. The seaweed holobiont: Understanding seaweed-bacteria interactions. FEMS Microbiol. Rev. 2013, 37, 462-476. [CrossRef]

137. Singh, R.P.; Kumari, P.; Reddy, C.R.K. Antimicrobial compounds from seaweeds-associated bacteria and fungi. Appl. Microbiol. Biotechnol. 2015, 99, 1571-1586. [CrossRef] 
138. Wichard, T.; Beemelmanns, C. Role of Chemical Mediators in Aquatic Interactions across the Prokaryote-Eukaryote Boundary. J. Chem. Ecol. 2018, 44, 1008-1021. [CrossRef] [PubMed]

139. Rämä, T.; Hassett, B.T.; Bubnova, E. Arctic marine fungi: From filaments and flagella to operational taxonomic units and beyond. Bot. Mar. 2017, 60, 433-452. [CrossRef]

140. Castro-Sowinski, S. The Ecological Role of Micro-Organisms in the Antarctic Environment; Springer: Berlin/Heidelberg, Germany, 2019; ISBN 3030027864.

141. D'Amico, S.; Collins, T.; Marx, J.C.; Feller, G.; Gerday, C. Psychrophilic microorganisms: Challenges for life. EMBO Rep. 2006, 7, 385-389. [CrossRef]

142. Cavicchioli, R.; Charlton, T.; Ertan, H.; Omar, S.M.; Siddiqui, K.S.; Williams, T.J. Biotechnological uses of enzymes from psychrophiles. Microb. Biotechnol. 2011, 4, 449-460. [CrossRef]

143. Corinaldesi, C. New perspectives in benthic deep-sea microbial ecology. Front. Mar. Sci. 2015, 2, 17. [CrossRef]

144. Chambergo, F.S.; Valencia, E.Y. Fungal biodiversity to biotechnology. Appl. Microbiol. Biotechnol. 2016, 100, 2567-2577. [CrossRef] [PubMed]

145. Coker, J.A. Extremophiles and biotechnology: Current uses and prospects. F1000Research 2016, 5, 396-403. [CrossRef] [PubMed]

146. Ul Arifeen, M.Z.; Ma, Y.N.; Xue, Y.R.; Liu, C.H. Deep-sea fungi could be the new arsenal for bioactive molecules. Mar. Drugs 2020, 18, 9. [CrossRef] [PubMed]

147. Buzzini, P.; Margesin, R. Cold-Adapted Yeasts: A Lesson from the Cold and a Challenge for the XXI Century. In Cold-Adapted Yeasts: Biodiversity, Adaptation Strategies and Biotechnological Significance; Buzzini, P., Margesin, R., Eds.; Springer: Berlin/Heidelberg, Germany, 2014; pp. 3-22. ISBN 978-3-642-39681-6.

148. Housman, G.; Byler, S.; Heerboth, S.; Lapinska, K.; Longacre, M.; Snyder, N.; Sarkar, S. Drug resistance in cancer: An overview. Cancers 2014, 6, 1769-1792. [CrossRef]

149. Ventola, C.L. The antibiotic resistance crisis: Part 1: Causes and threats. Pharm. Ther. 2015, 40, $277-283$.

150. Newman, D.J.; Cragg, G.M. Natural Products as Sources of New Drugs from 1981 to 2014. J. Nat. Prod. $2016,79,629-661$. [CrossRef]

151. Bernan, V.S.; Greenstein, M.; Maiese, W.M. Marine microorganisms as a source of new natural products. Adv. Appl. Microbiol. 1997, 43, 57-90.

152. Blunt, J.W.; Copp, B.R.; Keyzers, R.A.; Carroll, A.R.; Munro, M.M.H.G.; Prinsep, M.R.; Copp, B.R.; Davis, R.A.; Keyzers, R.A.; Prinsep, M.R. Marine natural products. Nat. Prod. Rep. 2016, 35, 8-53. [CrossRef]

153. Gerwick, W.H.; Moore, B.S. Lessons from the past and charting the future of marine natural products drug discovery and chemical biology. Chem. Biol. 2012, 19, 85-98. [CrossRef]

154. Bonugli-Santos, R.C.; dos Santos Vasconcelos, M.R.; Passarini, M.R.Z.; Vieira, G.A.L.; Lopes, V.C.P.; Mainardi, P.H.; dos Santos, J.A.; de Azevedo Duarte, L.; Otero, I.V.R.; da Silva Yoshida, A.M.; et al. Marine-derived fungi: Diversity of enzymes and biotechnological applications. Front. Microbiol. 2015, 6, 269. [CrossRef]

155. Imhoff, J.F. Natural products from marine fungi-Still an underrepresented resource. Mar. Drugs 2016, 14, 19. [CrossRef]

156. Demain, A.L. Importance of microbial natural products and the need to revitalize their discovery. J. Ind. Microbiol. Biotechnol. 2014, 41, 185-201. [CrossRef]

157. Gomes, N.; Lefranc, F.; Kijjoa, A.; Kiss, R. Can Some Marine-Derived Fungal Metabolites Become Actual Anticancer Agents? Mar Drugs 2015, 13, 3950-3991. [CrossRef]

158. Varrella, S.; Tangherlini, M.; Corinaldesi, C. Deep Hypersaline Anoxic Basins as Untapped Reservoir of Polyextremophilic Prokaryotes of Biotechnological Interest. Mar. Drugs 2020, 18, 91. [CrossRef]

159. Deshmukh, S.K.; Prakash, V.; Ranjan, N. Marine Fungi: A Source of Potential Anticancer Compounds: A Source of Potential Anticancer Compounds. Front. Microbiol. 2018, 8, 2536. [CrossRef]

160. Núñez-Pons, L.; Shilling, A.; Verde, C.; Baker, B.J.; Giordano, D. Marine Terpenoids from Polar Latitudes and Their Potential Applications in Biotechnology. Mar. Drugs 2020, 18, 401. [CrossRef]

161. Frisvad, J.C. Cold-Adapted Fungi as a Source for Valuable Metabolites. In Psychrophiles: From Biodiversity to Biotechnology; Margesin, R., Schinner, F., Marx, J.-C., Gerday, C., Eds.; Springer: Berlin/Heidelberg, Germany, 2008; pp. 381-387. ISBN 978-3-540-74335-4.

162. Zucconi, L.; Canini, F.; Temporiti, M.E.; Tosi, S. Extracellular Enzymes and Bioactive Compounds from Antarctic Terrestrial Fungi for Bioprospecting. Int. J. Environ. Res. Public Health 2020, 17, 6459. [CrossRef]

163. Lin, A.; Wu, G.; Gu, Q.; Zhu, T.; Li, D. New eremophilane-type sesquiterpenes from an Antarctic deep-sea derived fungus, Penicillium sp. PR19 N-1. Arch. Pharm. Res. 2014, 37, 839-844. [CrossRef]

164. ChemSpider Search and Share Chemistry. Available online: https:/ /www.chemspider.com/ (accessed on 7 May 2021).

165. Huang, J.-N.; Zou, Q.; Chen, J.; Xu, S.-H.; Luo, D.; Zhang, F.-G.; Lu, Y.-Y. Phenols and diketopiperazines isolated from Antarcticderived fungi, Penicillium citreonigrum SP-6. Phytochem. Lett. 2018, 27, 114-118. [CrossRef]

166. Hu, Z.Y.; Li, Y.Y.; Huang, Y.J.; Su, W.J.; Shen, Y.M. Three new sesquiterpenoids from Xylaria sp. NCY2. Helv. Chim. Acta 2008, 91, 46-52. [CrossRef]

167. Figueroa, L.; Jiménez, C.; Rodríguez, J.; Areche, C.; Chávez, R.; Henríquez, M.; de la Cruz, M.; Díaz, C.; Segade, Y.; Vaca, I. 3-Nitroasterric Acid Derivatives from an Antarctic Sponge-Derived Pseudogymnoascus sp. Fungus. J. Nat. Prod. 2015, 78, 919-923. [CrossRef] 
168. Li, Y.; Sun, B.; Liu, S.; Jiang, L.; Liu, X.; Zhang, H.; Che, Y. Bioactive Asterric Acid Derivatives from the Antarctic Ascomycete Fungus Geomyces sp. J. Nat. Prod. 2008, 71, 1643-1646. [CrossRef]

169. Ren, J.; Xue, C.; Tian, L.; Xu, M.; Chen, J.; Deng, Z.; Proksch, P.; Lin, W. Asperelines A-F, Peptaibols from the Marine-Derived Fungus Trichoderma asperellum. J. Nat. Prod. 2009, 72, 1036-1044. [CrossRef]

170. Gerday, C.; Aittaleb, M.; Bentahir, M.; Chessa, J.P.; Claverie, P.; Collins, T.; D'Amico, S.; Dumont, J.; Garsoux, G.; Georlette, D.; et al. Cold-adapted enzymes: From fundamentals to biotechnology. Trends Biotechnol. 2000, 18, $103-107$. [CrossRef]

171. Nandanwar, S.K.; Borkar, S.B.; Lee, J.H.; Kim, H.J. Taking Advantage of Promiscuity of Cold-Active Enzymes. Appl. Sci. 2020, 10, 8128. [CrossRef]

172. Sočan, J.; Purg, M.; Åqvist, J. Computer simulations explain the anomalous temperature optimum in a cold-adapted enzyme. Nat. Commun. 2020, 11, 2644. [CrossRef] [PubMed]

173. Liu, X.; Kokare, C. Chapter 11-Microbial Enzymes of Use in Industry. In Biotechnology of Microbial Enzymes Production, Biocatalysis and Industrial Applications; Brahmachari, G., Ed.; Academic Press: Cambridge, MA, USA, 2017; pp. 267-298. ISBN 978-0-12-803725-6.

174. Singh, R.; Kumar, M.; Mittal, A.; Mehta, P.K. Microbial enzymes: Industrial progress in 21st century. 3 Biotech 2016, 6, 174. [CrossRef]

175. Santiago, M.; Ramírez-Sarmiento, C.A.; Zamora, R.A.; Parra, L.P. Discovery, molecular mechanisms, and industrial applications of cold-active enzymes. Front. Microbiol. 2016, 7, 1408. [CrossRef]

176. De Maayer, P.; Anderson, D.; Cary, C.; Cowan, D.A. Some like it cold: Understanding the survival strategies of psychrophiles. EMBO Rep. 2014, 15, 508-517. [CrossRef]

177. Duarte, A.W.F.; dos Santos, J.A.; Vianna, M.V.; Vieira, J.M.F.; Mallagutti, V.H.; Inforsato, F.J.; Wentzel, L.C.P.; Lario, L.D.; Rodrigues, A.; Pagnocca, F.C.; et al. Cold-adapted enzymes produced by fungi from terrestrial and marine Antarctic environments. Crit. Rev. Biotechnol. 2018, 38, 600-619. [CrossRef]

178. Buzzini, P.; Branda, E.; Goretti, M.; Turchetti, B. Psychrophilic yeasts from worldwide glacial habitats: Diversity, adaptation strategies and biotechnological potential. FEMS Microbiol. Ecol. 2012, 82, 217-241. [CrossRef]

179. Flam, F. The chemistry of life at the margins. Science 1994, 265, 471-472. [CrossRef]

180. Dumorné, K.; Córdova, D.C.; Astorga-Eló, M.; Renganathan, P. Extremozymes: A potential source for industrial applications. J. Microbiol. Biotechnol. 2017, 27, 649-659. [CrossRef]

181. Bjelic, S.; Brandsdal, B.O.; Åqvist, J. Cold adaptation of enzyme reaction rates. Biochemistry 2008, 47, 10049-10057. [CrossRef]

182. Feller, G. Protein stability and enzyme activity at extreme biological temperatures. J. Phys. Condens. Matter 2010, $22,323101$. [CrossRef]

183. Feller, G. Psychrophilic Enzymes: From Folding to Function and Biotechnology. Scientifica 2013, 2013, 512840. [CrossRef]

184. Gerday, C. Psychrophily and Catalysis. Biology 2013, 2, 719-741. [CrossRef]

185. Sarmiento, F.; Peralta, R.; Blamey, J.M. Cold and Hot Extremozymes: Industrial Relevance and Current Trends. Front. Bioeng. Biotechnol. 2015, 3, 148. [CrossRef]

186. Martínez-Martínez, M.; Bargiela, R.; Ferrer, M. Metagenomics and the Search for Industrial Enzymes. In Biotechnology of Microbial Enzymes: Production, Biocatalysis and Industrial Applications; Brahmachari, G., Demain, A.L., Adrio, J.L., Eds.; Academic Press: Cambridge, MA, USA, 2016; pp. 167-184.

187. Jin, M.; Gai, Y.; Guo, X.; Hou, Y.; Zeng, R. Properties and Applications of Extremozymes from Deep-Sea Extremophilic Microorganisms: A Mini Review. Mar. Drugs 2019, 17, 656. [CrossRef]

188. Castilla, I.A.; Woods, D.F.; Reen, F.J.; O'Gara, F. Harnessing marine biocatalytic reservoirs for green chemistry applications through metagenomic technologies. Mar. Drugs 2018, 16, 227. [CrossRef]

189. Martorell, M.M.; Ruberto, L.A.M.; de Figueroa, L.I.C.; Mac Cormack, W.P. Antarctic Yeasts as a Source of Enzymes for Biotechnological Applications. In Fungi of Antarctica; Springer International Publishing: Berlin/Heidelberg, Germany, 2019 ; pp. $285-304$.

190. Arora, N.K.; Panosyan, H. Extremophiles: Applications and roles in environmental sustainability. Environ. Sustain. 2019, 2, 217-218. [CrossRef]

191. Burhan, H.; Ravinder, S.R.; Deepak, C.; Poonam, S.; Fayaz, A.M.; Sanjay, S.; Ishfaq, A. Psychrophilic yeasts and their biotechnological applications-A review. Afr. J. Biotechnol. 2014, 13, 2188-2197. [CrossRef]

192. Feller, G. Molecular adaptations to cold in psychrophilic enzymes. Cell. Mol. Life Sci. 2003, 60, 648-662. [CrossRef]

193. Feller, G.; Gerday, C. Psychrophilic enzymes: Hot topics in cold adaptation. Nat. Rev. Microbiol. 2003, 1, 200-208. [CrossRef]

194. Gomes, J.; Steiner, W. The biocatalytic potential of extremophiles and extremozymes. Food Technol. Biotechnol. 2004, 42, $223-235$.

195. Dalmaso, G.Z.L.; Ferreira, D.; Vermelho, A.B.; Zamith, G.; Dalmaso, L.; Ferreira, D.; Vermelho, A.B.; Dalmaso, G.Z.L.; Ferreira, D.; Vermelho, A.B. Marine Extremophiles: A Source of Hydrolases for Biotechnological Applications. Mar. Drugs 2015, 13, 1925-1965. [CrossRef]

196. Kuddus, M. Cold-active enzymes in food biotechnology: An updated mini review. J. Appl. Biol. Biotechnol. 2018, 6, 58-63.

197. Blamey, J.M.; Fischer, F.; Meyer, H.P.; Sarmiento, F.; Zinn, M. Enzymatic Biocatalysis in Chemical Transformations: A Promising and Emerging Field in Green Chemistry Practice. In Biotechnology of Microbial Enzymes: Production, Biocatalysis and Industrial Applications; Brahmachari, G., Demain, A.L., Adrio, J.L., Eds.; Academic Press: Cambridge, MA, USA, 2017 ; pp. $347-403$. ISBN 9780128037461. 
198. Fenice, M. The Psychrotolerant Antarctic Fungus Lecanicillium muscarium CCFEE 5003: A Powerful Producer of Cold-Tolerant Chitinolytic Enzymes. Molecules 2016, 21, 447. [CrossRef]

199. Barghini, P.; Moscatelli, D.; Garzillo, A.M.V.; Crognale, S.; Fenice, M. High production of cold-tolerant chitinases on shrimp wastes in bench-top bioreactor by the Antarctic fungus Lecanicillium muscarium CCFEE 5003: Bioprocess optimization and characterization of two main enzymes. Enzym. Microb. Technol. 2013, 53, 331-338. [CrossRef]

200. Ramli, A.N.M.; Mahadi, N.M.; Shamsir, M.S.; Rabu, A.; Joyce-Tan, K.H.; Murad, A.M.A.; Md. Illias, R. Structural prediction of a novel chitinase from the psychrophilic Glaciozyma antarctica PI12 and an analysis of its structural properties and function. J. Comput. Aided Mol. Des. 2012, 26, 947-961. [CrossRef]

201. Teoh, C.P.; Koh, S.P.; Ling, C.M.W.V. Characterisation of an Antarctic Yeast, Glaciozyma antarctica PI12. Borneo Int. J. Biotechnol. 2020, 1, 89. [CrossRef]

202. Bharudin, I.; Abu Bakar, M.F.; Hashim, N.H.F.; Mat Isa, M.N.; Alias, H.; Firdaus-Raih, M.; Md Illias, R.; Najimudin, N.; Mahadi, N.M.; Abu Bakar, F.D.; et al. Unravelling the adaptation strategies employed by Glaciozyma antarctica PI12 on Antarctic sea ice. Mar. Environ. Res. 2018, 137, 169-176. [CrossRef] [PubMed]

203. Mohammadi, S.; Hashim, N.H.F.; Mahadi, M.N.; Murad, A.M. The Cold-Active Endo- $\beta-1,3(4)$-Glucanase from a Marine Psychrophilic Yeast, Glaciozyma antarctica PI12: Heterologous Expression, Biochemical Characterisation, and Molecular Modeling. Int. J. Appl. Biol. Pharm. Technol. 2021, 12, 279-300. [CrossRef]

204. Mohammadi, S.; Parvizpour, S.; Razmara, J.; Abu Bakar, F.D.; Illias, R.M.; Mahadi, N.M.; Murad, A.M.A. Structure Prediction of a

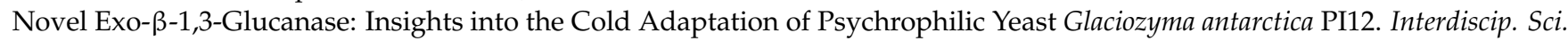
Comput. Life Sci. 2018, 10, 157-168. [CrossRef]

205. Hashim, N.H.F.; Mahadi, N.M.; Illias, R.M.; Feroz, S.R.; Abu Bakar, F.D.; Murad, A.M.A. Biochemical and structural characterization of a novel cold-active esterase-like protein from the psychrophilic yeast Glaciozyma antarctica. Extremophiles 2018, 22, 607-616. [CrossRef]

206. Duarte, A.W.F.; Barato, M.B.; Nobre, F.S.; Polezel, D.A.; de Oliveira, T.B.; dos Santos, J.A.; Rodrigues, A.; Sette, L.D. Production of cold-adapted enzymes by filamentous fungi from King George Island, Antarctica. Polar Biol. 2018, 41, 2511-2521. [CrossRef]

207. Duarte, A.W.F.; Lopes, A.M.; Molino, J.V.D.; Pessoa, A.; Sette, L.D. Liquid-liquid extraction of lipase produced by psychrotrophic yeast Leucosporidium scottii L117 using aqueous two-phase systems. Sep. Purif. Technol. 2015, 156, 215-225. [CrossRef]

208. Carrasco, M.; Rozas, J.M.; Barahona, S.; Alcaíno, J.; Cifuentes, V.; Baeza, M. Diversity and extracellular enzymatic activities of yeasts isolated from King George Island, the sub-Antarctic region. BMC Microbiol. 2012, 12, 251. [CrossRef]

209. Tsuji, M.; Yokota, Y.; Shimohara, K.; Kudoh, S.; Hoshino, T. An Application of Wastewater Treatment in a Cold Environment and Stable Lipase Production of Antarctic Basidiomycetous Yeast Mrakia blollopis. PLoS ONE 2013, 8, e59376. [CrossRef]

210. Poveda, G.; Gil-Durán, C.; Vaca, I.; Levicán, G.; Chávez, R. Cold-active pectinolytic activity produced by filamentous fungi associated with Antarctic marine sponges. Biol. Res. 2018, 51, 28. [CrossRef]

211. Yu, P.; Wang, X.-T.; Liu, J.-W. Purification and characterization of a novel cold-adapted phytase from Rhodotorula mucilaginosa strain JMUY14 isolated from Antarctic. J. Basic Microbiol. 2015, 55, 1029-1039. [CrossRef]

212. Lario, L.D.; Chaud, L.; das Graças Almeida, M.; Converti, A.; Durães Sette, L.; Pessoa, A.; Duraes Sette, L.; Pessoa, A.; Durães Sette, L.; Pessoa, A. Production, purification, and characterization of an extracellular acid protease from the marine Antarctic yeast Rhodotorula mucilaginosa L7. Fungal Biol. 2015, 119, 1129-1136. [CrossRef]

213. Chaud, L.C.S.; Lario, L.D.; Bonugli-Santos, R.C.; Sette, L.D.; Pessoa Junior, A.; Felipe, M.d.G.d.A. Improvement in extracellular protease production by the marine antarctic yeast Rhodotorula mucilaginosa L7. New Biotechnol. 2016, 33, 807-814. [CrossRef]

214. Turkiewicz, M.; Pazgier, M.; Kalinowska, H.; Bielecki, S. A cold-adapted extracellular serine proteinase of the yeast Leucosporidium antarcticum. Extremophiles 2003, 7, 435-442. [CrossRef]

215. Alias, N.; Ahmad Mazian, M.; Salleh, A.B.; Basri, M.; Rahman, R.N.Z.R.A. Molecular Cloning and Optimization for High Level Expression of Cold-Adapted Serine Protease from Antarctic Yeast Glaciozyma antarctica PI12. Enzym. Res. 2014, $2014,197938$. [CrossRef]

216. Glodowsky, A.P.; Ruberto, L.A.; Martorell, M.M.; Mac Cormack, W.P.; Levin, G.J. Cold active transglutaminase from antarctic Penicillium chrysogenum: Partial purification, characterization and potential application in food technology. Biocatal. Agric. Biotechnol. 2020, 29, 101807. [CrossRef]

217. Gil-Durán, C.; Ravanal, M.-C.; Ubilla, P.; Vaca, I.; Chávez, R. Heterologous expression, purification and characterization of a highly thermolabile endoxylanase from the Antarctic fungus Cladosporium sp. Fungal Biol. 2018, 122, 875-882. [CrossRef]

218. Del-Cid, A.; Ubilla, P.; Ravanal, M.-C.M.-C.C.; Medina, E.; Vaca, I.; Levican, G.; Eyzaguirre, J.; Chavez, R.; Levicán, G.; Eyzaguirre, J.; et al. Cold-Active Xylanase Produced by Fungi Associated with Antarctic Marine Sponges. Appl. Biochem. Biotechnol. 2014, 172, 524-532. [CrossRef]

219. Azhar, M. Cloning, Expression and Analysis of $\alpha$-Amylase Gene from Psychrophilic Yeast Leucosporidium antarcticum PI12. Ph.D. Thesis, Universiti Teknologi Malaysia, Skudai, Malaysia, 2012.

220. Song, C.; Liu, G.L.; Xu, J.L.; Chi, Z.M. Purification and characterization of extracellular $\beta$-galactosidase from the psychrotolerant yeast Guehomyces pullulans 17-1 isolated from sea sediment in Antarctica. Process Biochem. 2010, 45, 954-960. [CrossRef]

221. Erich, S.; Kuschel, B.; Schwarz, T.; Ewert, J.; Böhmer, N.; Niehaus, F.; Eck, J.; Lutz-Wahl, S.; Stressler, T.; Fischer, L. Novel high-performance metagenome $\beta$-galactosidases for lactose hydrolysis in the dairy industry. J. Biotechnol. 2015, $210,27-37$. [CrossRef] 
222. Ugidos-Rodríguez, S.; Matallana-González, M.C.; Sánchez-Mata, M.C. Lactose malabsorption and intolerance: A review. Food Funct. 2018, 9, 4056-4068. [CrossRef] [PubMed]

223. Collins, T.; Gerday, C.; Feller, G. Xylanases, xylanase families and extremophilic xylanases. FEMS Microbiol. Rev. 2005, 29 , 3-23. [CrossRef] [PubMed]

224. Collins, T.; Gerday, C.; Feller, G.; Polizeli, M.L.T.M.; Rizzatti, A.C.S.; Monti, R.; Terenzi, H.F.; Jorge, J.A.; Amorim, D.S. Xylanases from fungi: Properties and industrial applications. Appl. Microbiol. Biotechnol. 2005, 67, 577-591.

225. Bhardwaj, N.; Kumar, B.; Verma, P. A detailed overview of xylanases: An emerging biomolecule for current and future prospective. Bioresour. Bioprocess. 2019, 6, 40. [CrossRef]

226. Guerrand, D. Lipases industrial applications: Focus on food and agroindustries. OCL 2017, 24, D403. [CrossRef]

227. Gurung, N.; Ray, S.; Bose, S.; Rai, V. A broader view: Microbial enzymes and their relevance in industries, medicine, and beyond. Biomed. Res. Int. 2013, 2013, 329121. [CrossRef]

228. Chandra, P.; Enespa; Singh, R.; Arora, P.K. Microbial lipases and their industrial applications: A comprehensive review. Microb. Cell Fact. 2020, 19, 169. [CrossRef]

229. Al-Ghanayem, A.A.; Joseph, B. Current prospective in using cold-active enzymes as eco-friendly detergent additive. Appl. Microbiol. Biotechnol. 2020, 104, 2871-2882. [CrossRef]

230. Kavitha, M. Cold active lipases-An update. Front. Life Sci. 2016, 9, 226-238. [CrossRef]

231. Vakhlu, J.; Kour, A. Yeast lipases: Enzyme purification, biochemical properties and gene cloning. Electron. J. Biotechnol. 2006, 9 , 717-3458. [CrossRef]

232. Domínguez De María, P.; Carboni-Oerlemans, C.; Tuin, B.; Bargeman, G.; Van Der Meer, A.; Van Gemert, R. Biotechnological applications of Candida antarctica lipase A: State-of-the-art. J. Mol. Catal. B Enzym. 2005, 37, 36-46. [CrossRef]

233. Szczesna-Antczak, M.; Kamińska, J.; Florczak, T.; Turkiewicz, M. Cold-active yeast lipases: Recent issues and future prospects. In Cold-Adapted Yeasts: Biodiversity, Adaptation Strategies and Biotechnological Significance; Springer: Berlin/Heidelberg, Germany, 2013; pp. 353-375. ISBN 9783642396816.

234. Joseph, B.; Ramteke, P.W.; Thomas, G. Cold active microbial lipases: Some hot issues and recent developments. Biotechnol. Adv. 2008, 26, 457-470. [CrossRef]

235. Martorell, M.M.; Ruberto, L.A.M.; Fernández, P.M.; Castellanos de Figueroa, L.I.; Mac Cormack, W.P. Bioprospection of coldadapted yeasts with biotechnological potential from Antarctica. J. Basic Microbiol. 2017, 57, 504-516. [CrossRef]

236. Cabrera, M.Á.; Blamey, J.M. Biotechnological applications of archaeal enzymes from extreme environments. Biol. Res. 2018, 51, 37. [CrossRef]

237. Furhan, J. Adaptation, production, and biotechnological potential of cold-adapted proteases from psychrophiles and psychrotrophs: Recent overview. J. Genet. Eng. Biotechnol. 2020, 18, 36. [CrossRef]

238. Razzaq, A.; Shamsi, S.; Ali, A.; Ali, Q.; Sajjad, M.; Malik, A.; Ashraf, M. Microbial proteases applications. Front. Bioeng. Biotechnol. 2019, 7, 110. [CrossRef]

239. Sharma, K.M.; Kumar, R.; Panwar, S.; Kumar, A. Microbial alkaline proteases: Optimization of production parameters and their properties. J. Genet. Eng. Biotechnol. 2017, 15, 115-126. [CrossRef]

240. Grossart, H.P.; Wurzbacher, C.; James, T.Y.; Kagami, M. Discovery of dark matter fungi in aquatic ecosystems demands a reappraisal of the phylogeny and ecology of zoosporic fungi. Fungal Ecol. 2016, 19, 28-38. [CrossRef]

241. Overy, D.P.; Rämä, T.; Oosterhuis, R.; Walker, A.K.; Pang, K.L. The neglected marine fungi, sensu stricto, and their isolation for natural products' discovery. Mar. Drugs 2019, 17, 42. [CrossRef]

242. Vester, J.K.; Glaring, M.A.; Stougaard, P. Improved cultivation and metagenomics as new tools for bioprospecting in cold environments. Extremophiles 2015, 19, 17-29. [CrossRef] [PubMed]

243. Amann, R.I.; Ludwig, W.; Schleifer, K.-H. Phylogenetic Identification and In Situ Detection of Individual Microbial Cells without Cultivation. Microbiol. Rev. 1995, 59, 143-169. [CrossRef] [PubMed]

244. Solden, L.; Lloyd, K.; Wrighton, K. The bright side of microbial dark matter: Lessons learned from the uncultivated majority. Curr. Opin. Microbiol. 2016, 31, 217-226. [CrossRef] [PubMed]

245. Ambrosino, L.; Tangherlini, M.; Colantuono, C.; Esposito, A.; Sangiovanni, M.; Miralto, M.; Sansone, C.; Chiusano, M.L. Bioinformatics for Marine Products: An Overview of Resources, Bottlenecks, and Perspectives. Mar. Drugs 2019, $17,576$. [CrossRef] [PubMed]

246. Barone, R.; De Santi, C.; Palma Esposito, F.; Tedesco, P.; Galati, F.; Visone, M.; Di Scala, A.; De Pascale, D. Marine metagenomics, a valuable tool for enzymes and bioactive compounds discovery. Front. Mar. Sci. 2014, 1, 38. [CrossRef]

247. Madhavan, A.; Sindhu, R.; Parameswaran, B.; Sukumaran, R.K.; Pandey, A. Metagenome Analysis: A Powerful Tool for Enzyme Bioprospecting. Appl. Biochem. Biotechnol. 2017, 183, 636-651. [CrossRef]

248. Hug, J.J.; Bader, C.D.; Remškar, M.; Cirnski, K.; Müller, R. Concepts and methods to access novel antibiotics from actinomycetes. Antibiotics 2018, 7, 44. [CrossRef]

249. Zhang, M.M.; Qiao, Y.; Ang, E.L.; Zhao, H. Using natural products for drug discovery: The impact of the genomics era. Expert Opin. Drug Discov. 2017, 12, 475-487. [CrossRef]

250. Skellam, E. Strategies for Engineering Natural Product Biosynthesis in Fungi. Trends Biotechnol. 2019, 37, 416-427. [CrossRef] 
251. Goyal, D.; Swaroop, S.; Pandey, J. Harnessing the Genetic Diversity and Metabolic Potential of Extremophilic Microorganisms through the Integration of Metagenomics and Single-Cell Genomics. In Extremophilic Microbes and Metabolites-Diversity, Bioprespecting and Biotechnological Applications; IntechOpen: London, UK, 2021.

252. Milshteyn, A.; Schneider, J.S.; Brady, S.F. Mining the metabiome: Identifying novel natural products from microbial communities. Chem. Biol. 2014, 21, 1211-1223. [CrossRef] 